\title{
BDNF Interacts with Endocannabinoids to Regulate Cocaine- Induced Synaptic Plasticity in Mouse Midbrain Dopamine Neurons
}

\author{
Peng Zhong, ${ }^{1 *}$ Yong Liu, ${ }^{1,2 *}$ Ying Hu, ${ }^{1}$ Tong Wang, ${ }^{1}{ }^{\circ}$ Yong-ping Zhao, ${ }^{1,3}$ and Qing-song Liu ${ }^{1}$ \\ ${ }^{1}$ Department of Pharmacology and Toxicology, Medical College of Wisconsin, Milwaukee, Wisconsin 53226, ${ }^{2}$ Research Center for Biochemistry \& Molecular \\ Biology, Jiangsu Key Laboratory of Brain Disease Bioinformation, Xuzhou Medical College, Jiangsu, 221002, China, and ${ }^{3}$ Reproductive Center, Peking \\ University People's Hospital, Beijing, 100044, China
}

Brain-derived neurotrophic factor (BDNF) and endocannabinoids (eCBs) have been individually implicated in behavioral effects of cocaine. The present study examined how BDNF-eCB interaction regulates cocaine-induced synaptic plasticity in the ventral tegmental area and behavioral effects. We report that BDNF and selective tyrosine kinase receptor B (TrkB) agonist 7,8-dihydroxyflavone (DHF) activated the TrkB receptor to facilitate two forms of eCB-mediated synaptic depression, depolarization-induced suppression of inhibition (DSI), and long-term depression (I-LTD) of IPSCs in ventral tegmental area dopamine neurons in mouse midbrain slices. The facilitation appears to be mediated by an increase in $\mathrm{eCB}$ production via phospholipase $\mathrm{C} \gamma$ pathway, but not by an increase in $\mathrm{CB}_{1}$ receptor responsiveness or a decrease in eCB hydrolysis. Using Cre-loxP technology to specifically delete BDNF in dopamine neurons, we showed that eCB-mediated I-LTD, cocaine-induced reduction of GABAergic inhibition, and potentiation of glutamatergic excitation remained intact in wild-type control mice, but were impaired in BDNF conditional knock-out mice. We also showed that cocaine-induced conditioned place preference was attenuated in BDNF conditional knock-out mice, in vivo pretreatments with DHF before place conditioning restored cocaine conditioned place preference in these mice, and the behavioral effect of DHF was blocked by a $\mathrm{CB}_{1}$ receptor antagonist. Together, these results suggest that BDNF in dopamine neurons regulates eCB responses, cocaine-induced synaptic plasticity, and associative learning.

Key words: BDNF; cocaine; conditioned place preference; DSI; endocannabinoid; I-LTD

\section{Introduction}

Drugs of abuse, such as cocaine, induce long-term neuroadaptations in the reward circuit that lead to addictive behavior (Hyman et al., 2006). Brain-derived neurotrophic factor (BDNF) and endocannabinoids (eCBs) are important for activity-dependent synaptic plasticity and drug-induced neuroadaptations (Gerdeman et al., 2003; Lupica and Riegel, 2005; Heifets and Castillo, 2009; McGinty et al., 2010; Park and Poo, 2013). BDNF and eCBs are released in response to neuronal activity and are key regulators of long-term synaptic plasticity (Heifets and Castillo, 2009; Park and Poo, 2013). BDNF in the mesolimblic dopamine system is elevated following cocaine withdrawal (Grimm et al., 2003); the increased BDNF following cocaine withdrawal facilitates LTP in

\footnotetext{
Received July 16, 2014; revised Jan. 11, 2015; accepted Feb. 10, 2015.

Author contributions: P.Z., Y.L., Y.-p.Z., and Q.-s.L. designed research; P.Z., Y.L., Y.H., and T.W. performed research; P.Z., Y.L., Y.H., and T.W. analyzed data; P.Z., Y.L., Y.-p.Z., and Q.-s.L. wrote the paper.

This work was supported by National Institutes of Health Grants DA035217 and MH101146 and in part by the Research and Education Initiative Fund, a component of the Advancing a Healthier Wisconsin endowment at the Medical College of Wisconsin.

The authors declare no competing financial interests.

*P.Z. and Y.L. contributed equally to this work.

Correspondence should be addressed to Dr. Qing-song Liu, Department of Pharmacology and Toxicology, Medical College of Wisconsin, 8701 Watertown Plank Road, Milwaukee, WI 53226. E-mail: qsliu@mcw.edu.

DOI:10.1523/JNEUROSCI.2924-14.2015

Copyright $\odot 2015$ the authors $\quad 0270-6474 / 15 / 354469-13 \$ 15.00 / 0$
}

the ventral tegmental area (VTA) (Pu et al., 2006) and prefrontal cortex (Lu et al., 2010). Pharmacological and genetic manipulations of BDNF and its receptor tyrosine kinase receptor B (TrkB) altered cocaine self-administration, conditioned place preference (CPP), and behavioral sensitization (Berglind et al., 2007; Graham et al., 2007; Bahi et al., 2008; Lobo et al., 2010; Lu et al., 2010; Huang et al., 2011). The eCB system has been implicated in habit learning and cocaine seeking (for review, see Gerdeman et al., 2003; Lupica and Riegel, 2005). eCBs mediate short-term and long-term depression (LTD) at excitatory and inhibitory synapses (I-LTD) (Gerdeman et al., 2002; Marsicano et al., 2002; Robbe et al., 2002; Chevaleyre and Castillo, 2003). eCB-mediated synaptic plasticity represents a widespread and fundamental mechanism by which synaptic strength and behavior can be regulated (Gerdeman et al., 2003; Heifets and Castillo, 2009). Recent studies suggest a strong interaction between $\mathrm{BDNF}$ and the eCB system (Luongo et al., 2014). BDNF increases $\mathrm{CB}_{1}$ receptor expression in cultured cerebellar granule neurons (Maison et al., 2009). BDNF depresses IPSCs in neocortical layer $2 / 3$ pyramidal neurons, and this depression is mediated by $\mathrm{CB}_{1}$ receptors (Lemtiri-Chlieh and Levine, 2010; Zhao and Levine, 2014). In contrast, $\mathrm{BDNF}$ inhibited $\mathrm{CB}_{1}$ agonist-induced depression of IPSCs in the striatum through a mechanism mediated by altered cholesterol metabolism and membrane lipid raft function (De 
Chiara et al., 2010). However, it remains poorly understood whether and how BDNF interacts with eCBs to regulate cocaineinduced synaptic plasticity.

We have shown that repeated cocaine exposure in vivo reduces GABAergic inhibition onto VTA dopamine neurons, and eCBmediated I-LTD might constitute a mechanism for cocaineinduced reduction of GABAergic inhibition (Liu et al., 2005; Pan et al., 2008b). The present study investigated the role and mechanism by which BDNF-eCB interaction regulates cocaineinduced synaptic plasticity in VTA dopamine neurons. Using Cre-loxP technology to specifically delete BDNF in dopamine neurons, we showed that eCB-mediated I-LTD, cocaine-induced reduction of GABAergic inhibition, and potentiation of glutamatergic excitation were impaired following conditional knock-out (cKO) of BDNF in dopamine neurons. These results suggest that BDNF-eCB interaction is required for cocaine-induced inhibitory synaptic plasticity in VTA dopamine neurons. In addition, $B D N F$ cKO mice exhibited impaired CPP to cocaine, suggesting that cue-drug associated learning was impaired in these mice.

\section{Materials and Methods}

Animals. Animal maintenance and use were in accordance with protocols approved by the Institutional Animal Care and Use Committee of the Medical College of Wisconsin. C57BL/6J mice (Jax stock \#000664), homozygous BDNF-floxed mice ( $B d n f^{\text {foxP } / l o x P}$, Jax stock \#004339), heterozygous DAT-Cre ${ }^{+/-}$mice (Jax stock \#006660), and ROSA26-floxSTOP-flox-lacZ (R26R) reporter mice (Jax stock \#003474) were obtained from The Jackson Laboratory. R26R mice were crossed with DAT$\mathrm{Cre}^{+/-}$mice to examine the Cre expression and effectiveness of recombination. Expression of Cre recombinase was identified by immunofluorescence staining of $\beta$-galactosidase $(\beta$-gal). To generate dopamine neuron-specific BDNF $c K O$ mice, we crossed $B d n f$ foxPlloxP mice with DAT-Cre $e^{+/-}$mice to produce a compound, DAT-Cre ${ }^{+/-}$/ $B d n f^{\text {doxP/wt }}$ mouse line. BDNF cKO (DAT-Cre $\left.e^{+-} / B d n f^{\text {foxP } / l o x P}\right)$ mice were generated by crossing this compound, DAT-Cre ${ }^{+/-} / B d n f^{\text {toxP } / w t}$ mice with $B d n f^{\text {oxP } / l o x P}$ mice. DAT-Cre $e^{+/-} / B D N F^{\text {loxP/wt }}$ or DAT-Cre $e^{-/-} / B d n f^{\text {foxP } / o x P}$ mice were used as wild-type controls. Genotyping analysis was performed by using standard PCR technique on tail biopsies. BDNF mRNA levels in the VTA were further determined by real-time PCR.

Brain slice preparation. C57BL/6J mice, BDNF cKO mice, and their wild-type littermates (P18-P30) of either sex were used for slice electrophysiology. Mice were anesthetized by isoflurane inhalation and decapitated. Horizontal midbrain slices were prepared at $250 \mu \mathrm{m}$ thickness using a Leica vibrating slicer as described previously (Pan et al., 2008b). Slices were prepared at $4^{\circ} \mathrm{C}-6^{\circ} \mathrm{C}$ in a sucrose-based solution containing the following (in mM): 220 sucrose, $2.5 \mathrm{KCl}, 1.25 \mathrm{NaH}_{2} \mathrm{PO}_{4}, 0.5 \mathrm{CaCl}_{2}, 7$ $\mathrm{MgSO}_{4}, 26 \mathrm{NaHCO}_{3}, 10$ glucose, 11.6 sodium ascorbate, and 3.1 sodium pyruvate. The slices were immediately transferred to oxygenated $(95 \%$ $\mathrm{O}_{2} / 5 \% \mathrm{CO}_{2}$ ) ACSF containing the following (in $\mathrm{mM}$ ): $125 \mathrm{NaCl}, 2.5 \mathrm{KCl}$, $2 \mathrm{CaCl}_{2}, 1 \mathrm{MgCl}_{2}, 1.25 \mathrm{NaH}_{2} \mathrm{PO}_{4}, 26 \mathrm{NaHCO}_{3}$, and 10 glucose. The slices were allowed to recover at $35^{\circ} \mathrm{C}$ for $30 \mathrm{~min}$ and then incubated at room temperature for at least $30 \mathrm{~min}$ before patch-clamp recordings.

Electrophysiology. Whole-cell patch-clamp recordings were made using patch-clamp amplifiers (Multiclamp 700B) under infrareddifferential interference contrast microscopy. Data acquisition and analysis were performed using DigiData 1440A digitizer and analysis software pClamp 10 (Molecular Devices). Signals were filtered at $2 \mathrm{kHz}$ and sampled at $10 \mathrm{kHz}$. Dopamine neurons in the VTA were identified by long duration $(>1.5 \mathrm{~ms})$ of spontaneous action potentials in cell-attached configuration (Chieng et al., 2011) and the presence of large $I_{h}$ currents, rhythmic firing at low frequency, and prominent afterhyperpolarization in whole-cell mode (Johnson and North, 1992; Jones and Kauer, 1999; Liu et al., 2005). Neurons were voltage-clamped at $-70 \mathrm{mV}$ unless stated otherwise. For recording of evoked IPSCs, electrical stimulation was delivered by a bipolar tungsten stimulation electrode (WPI) that was placed $\sim 150 \mu \mathrm{m}$ rostral to the recorded dopamine neuron. Glutamate receptor antagonists CNQX $(20 \mu \mathrm{M})$ and D-AP-5 $(50 \mu \mathrm{M})$ were present in the ACSF throughout the experiments. For the experiments of depolarization-induced suppression of inhibition (DSI), glass pipettes (3-5 $\mathrm{M} \Omega$ ) were filled with an internal solution containing the following (in $\mathrm{mM}$ ): 80 Cs-methanesulfonate, $60 \mathrm{CsCl}, 2 \mathrm{QX}-314,10$ HEPES, 0.2 EGTA, $2 \mathrm{MgCl}_{2}, 4 \mathrm{MgATP}, 0.3 \mathrm{Na}_{2} \mathrm{GTP}$, and $10 \mathrm{Na}_{2}$-phosphocreatine ( $\mathrm{pH} 7.2$ with $\mathrm{CsOH}$ ). To induce DSI, neurons were depolarized from -70 to $0 \mathrm{mV}$ for $5 \mathrm{~s}$, and IPSCs were evoked at $4 \mathrm{~s}$ intervals. For recording of maximal IPSCs (see Fig. $8 A$ ), neurons were voltage-clamped at -20 $\mathrm{mV}$, and glass pipettes were filled with an internal solution containing the following (in $\mathrm{mm}$ ): 135 Cs-methanesulfonate, $5 \mathrm{CsCl}, 10$ HEPES, 1 EGTA, $2 \mathrm{MgCl}_{2}, 4 \mathrm{Mg}$-ATP, $0.3 \mathrm{Na}_{2} \mathrm{GTP}$, and $10 \mathrm{Na}_{2}$-phosphocreatine ( $\mathrm{pH}$ 7.2 with $\mathrm{CsOH}$ ). Maximal IPSCs were elicited by gradually increasing the stimulation intensity to recruit saturating IPSCs (Huang et al., 1999; Liu et al., 2005; Pan et al., 2008b). For recording of (S)-3,5dihydroxyphenylglycine (DHPG)-induced inward currents, the recording pipette was filled with same internal solution as that of maximal IPSCs. A glass pipette $(3-5 \mathrm{M} \Omega$ ) was filled with ACSF containing $10 \mu \mathrm{M}$ DHPG, the tip of the pipette was positioned $\sim 100 \mu \mathrm{m}$ to the recorded neurons. DHPG was pressure injected via a Spritzer (Toohey). GABA $\mathrm{A}$ receptor blocker picrotoxin $(50 \mu \mathrm{M})$ and AMPA receptor antagonist CNQX $(10 \mu \mathrm{M})$ were present in the ACSF. For I-LTD and mIPSC experiments, glass pipettes were filled with an internal solution containing the following (in mM): $100 \mathrm{~K}$-gluconate, $50 \mathrm{KCl}, 10 \mathrm{HEPES}, 0.2 \mathrm{EGTA}, 2 \mathrm{MgCl}_{2}, 4$ Mg-ATP, $0.3 \mathrm{Na}_{2} \mathrm{GTP}$, and $10 \mathrm{Na}_{2}$-phosphocreatine ( $\mathrm{pH} 7.2$ with $\mathrm{KOH}$ ). mIPSCs were recorded in the presence of $\mathrm{Na}^{+}$channel blocker tetrodotoxin (TTX, $0.5 \mu \mathrm{M}$ ).

AMPA/NMDA receptor (AMPAR/NMDAR) ratio was measured based on published studies (Saal et al., 2003; Liu et al., 2005). Evoked EPSCs were recorded from dopamine neurons in the presence of $\mathrm{GABA}_{\mathrm{A}}$ receptor blocker picrotoxin $(50 \mu \mathrm{M})$. Glass pipettes were filled with an internal solution containing the following (in $\mathrm{mM}$ ): 140 Cs-methanesulfonate, 10 HEPES, 1 EGTA, 5 tetraethylammonium chloride (TEA-Cl), $2.5 \mathrm{MgATP}, 0.3 \mathrm{Na}_{2} \mathrm{GTP}$, and $2 \mathrm{MgCl}_{2}$ (pH 7.2 with $\mathrm{CsOH}$ ). Neurons were voltage-clamped at $40 \mathrm{mV}$ to record dualcomponent EPSCs containing both AMPAR- and NMDAR-EPSCs that were isolated pharmacologically. After a stable baseline recording of total EPSCs, NMDAR antagonist D-AP5 $(50 \mu \mathrm{M})$ was then applied in the bath for 6-10 min to isolate fast AMPAR EPSCs. NMDAR-EPSCs were calculated as the subtraction of AMPAR-EPSCs from the total EPSCs from the same neuron. An average of 10-20 consecutive EPSCs was collected for the each type of EPSCs. The AMPAR/NMDAR ratio was calculated by dividing the peak of the AMPAR-EPSC by the peak of the NMDAR-EPSC.

Series resistance (15-30 $\mathrm{M} \Omega$ ) was monitored throughout all recordings, and data were discarded if the resistance changed by $>20 \%$. All recordings were performed at $32 \pm 1^{\circ} \mathrm{C}$ using an automatic temperature controller (Warner Instruments).

Immunofluorescence staining. The experimental procedure was conducted as we have previously described (Zhong et al., 2014). Mice were anesthetized by isoflurane, and the brain was fixed by transcardial perfusion with $0.1 \mathrm{~m}$ sodium PBS followed by $4 \%$ PFA in $4 \%$ sucrose-PBS, $\mathrm{pH}$ 7.4. The brain was then removed, postfixed in the same fixative for $4 \mathrm{~h}$ at $4^{\circ} \mathrm{C}$, dehydrated in gradual concentrations of sucrose $(20 \%$ and $30 \%)$ in $0.1 \mathrm{M} \mathrm{PBS}$ at $4^{\circ} \mathrm{C}$, and frozen on dry ice. Coronal VTA sections were made at $20 \mu \mathrm{m}$ thickness with a cryostat. The sections were incubated with primary antibodies against $\beta$-gal (chicken, 1:1000, Abcam) and TH (rabbit, 1:300, Santa Cruz Biotechnology) at $4^{\circ} \mathrm{C}$ for $48 \mathrm{~h}$. After rinsing three times at $10 \mathrm{~min}$ each in PBS, the sections were incubated in the different secondary antibodies: anti-chicken IgG AlexaFluor-568 conjugate (1:1000, Invitrogen) and anti-rabbit IgG AlexaFluor-488 conjugate (1:500, Cell Signaling Technology) for $4 \mathrm{~h}$ at room temperature in the dark. The sections were analyzed using a Nikon Eclipse TE-2000U confocal microscope.

RNA isolation, cDNA synthesis, and real-time PCR. To examine BDNF mRNA levels in the VTA, BDNF $c K O$ and wild-type control mice were anesthetized by isoflurane inhalation and decapitated. VTA punches were dissected out in RNase-free environment and were homogenized for total RNA isolation using an RNA mini kit (Invitrogen) according to the manufacturer's instructions. Extracted total RNA was treated by 

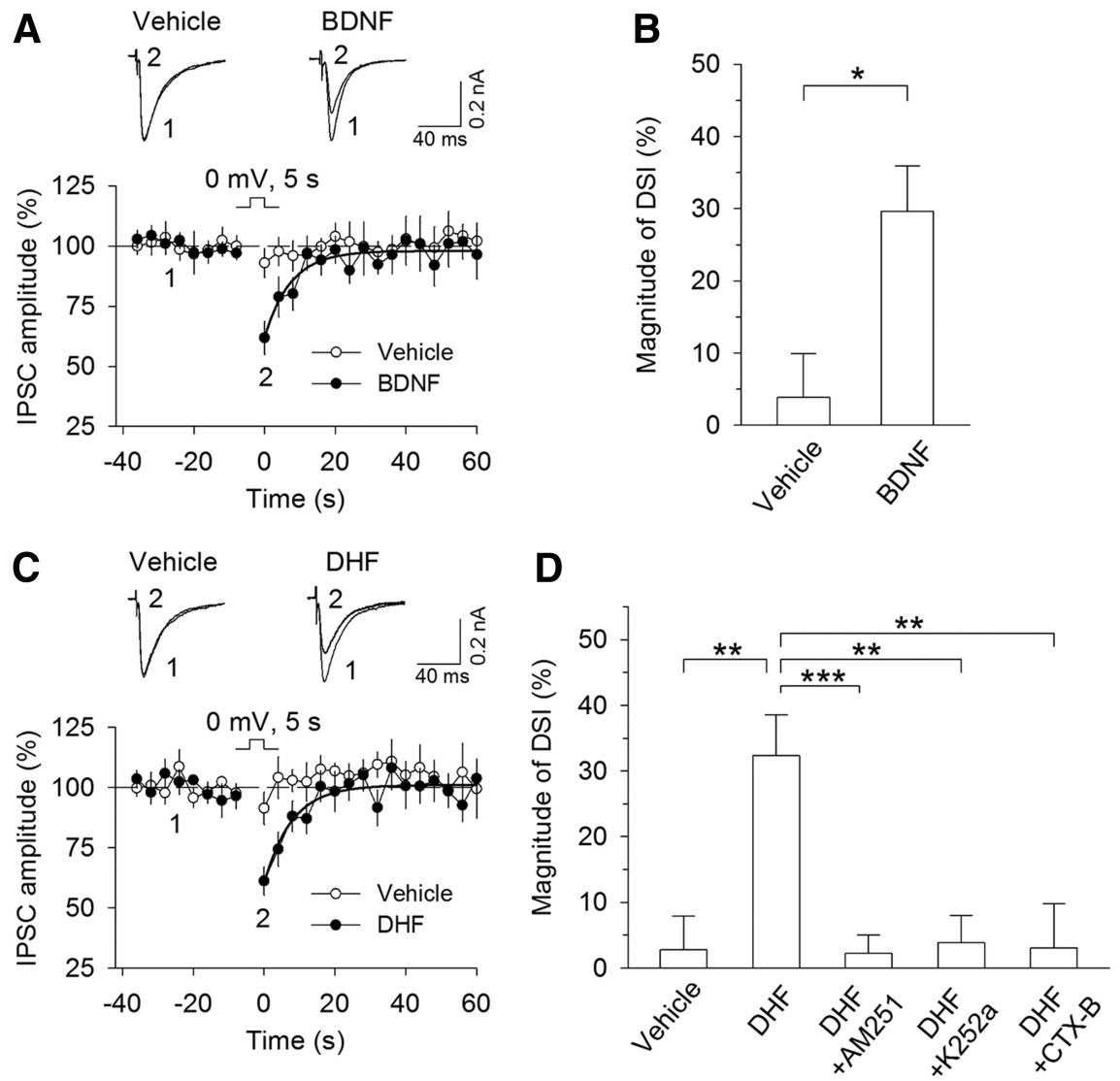

Figure 1. TrkB receptor agonists enabled DSI in VTA dopamine neurons. $A, A$ brief depolarization ( $5 \mathrm{~s}$ from -70 to $0 \mathrm{mV}$ ) did not induce significant depression of IPSCs in VTA dopamine neurons, whereas bath application of BDNF $(20 \mathrm{ng} / \mathrm{ml})$ enabled DSI. Shown are sample traces of evoked IPSCS (top) and averaged DSI (bottom). Solid lines indicate single exponential fitting curves of the decay of DSI. B, Summary of the magnitude of DSI in the presence of vehicle or BDNF $(20 \mathrm{ng} / \mathrm{ml})(n=8$ or 9$)$. ${ }^{*} p<0.05$. C, D, Bath application of TrkB receptor agonist DHF $(10 \mu \mathrm{m})$ enabled DSI $\left(n=10\right.$ or 11 ; $\left.{ }^{* *} p<0.01\right)$, which was blocked by the $C_{1}$ receptor antagonist AM251 ( $\left.2 \mu \mathrm{M} ; n=9 ;{ }^{* * *} p<0.001\right)$, the TrkB receptor inhibitor K252a (200 nm; $\left.n=9 ;{ }^{* *} p<0.01\right)$, or the TrkB receptor antagonist CTX-B (100 nм; $\left.n=12 ;{ }^{* *} p<0.01\right)$. Error bars indicate SEM.

DNase (Bio-Rad) for 15 min to eliminate possible DNA contamination. RNA was reverse transcribed into cDNA with an iScript cDNA synthesis kit (Bio-Rad). Levels of BDNF and $\beta$-actin mRNAs were quantified by real-time quantitative PCR using the following primers: BDNF, $5^{\prime}$ CTCAGGCAGAATGAGCAATG-3' and $5^{\prime}$-AGCCGTCTGTGCTCTTCACT- $3^{\prime} ; \beta$-actin: $5^{\prime}$-GTGACGTTGACATCCGTAAAGA- $3^{\prime}$ and $5^{\prime}$-GCCGGACTCATCGTACTCC-3'. Real-time quantitative PCR was performed on a Bio-Rad CFX96 RT system using a SYBR Green supermix kit (Bio-Rad). The $\Delta \Delta \mathrm{C}_{\mathrm{T}}$ method was used to quantify BDNF expression levels based on normalization to $\beta$-actin.

$C P P$. Cocaine CPP experiments were performed with a three-chamber apparatus (Med Associates). The CPP protocol consisted of the following sessions: (1) Pretest (day 1): BDNF cKO and wild-type control mice (2-3 months old) were allowed to explore three chambers freely for $20 \mathrm{~min}$, and time spent in every chamber was recorded. Mice showing unconditioned side preference ( $\geq 180 \mathrm{~s}$ disparity) were excluded. (2) Conditioning (day 2-7): Cocaine conditioning. On days 2, 4, and 6, mice received cocaine injection $(15 \mathrm{mg} / \mathrm{kg}$, i.p.) and were immediately confined to one chamber for $30 \mathrm{~min}$. On days 3, 5, and 7, mice received saline injection $(0.9 \% \mathrm{NaCl}, 1 \mathrm{ml} / \mathrm{kg}$, i.p. $)$ and were immediately confined to the opposite chamber for $30 \mathrm{~min}$. Saline conditioning. Mice received daily saline injection $(0.9 \% \mathrm{NaCl}, 1 \mathrm{ml} / \mathrm{kg}$, i.p.) and were immediately confined to one chamber for $30 \mathrm{~min}$ on days 3,5 , and 7 and were confined to the opposite chamber for $30 \mathrm{~min}$ on days 2, 4, and 6. (3) CPP test (day 8): All of the animals were allowed to explore freely for $20 \mathrm{~min}$ between the two sides, and time spent on each side was recorded (see Figs. 10 and 11). In separate experiments (see Figs. 10C,D and 11), control and BDNF cKO mice received intraperitoneal injections of vehicle, 7,8-dihydroxyflavone
(DHF; $5 \mathrm{mg} / \mathrm{kg}$ ), AM251 (3 $\mathrm{mg} / \mathrm{kg})$, and DHF + AM251 30 min before each saline or cocaine conditioning, and CPP was performed as described above.

Statistics. Data are presented as mean \pm SEM. The magnitude and decay constant $(\tau)$ of DSI and I-LTD were calculated as we have described (Pan et al., 2008b, 2009). mIPSCs were analyzed using Mini-analysis (Synaptosft) (Pan et al., 2008a). CPP scores were calculated as the time spent in cocaine-conditioned chamber minus that in saline-conditioned chamber (Zhong et al., 2012; Yu et al., 2013). Datasets were compared with either Student's $t$ test, one-way or two-way ANOVA followed by Tukey's post hoc analysis. Results were considered to be significant at $p<0.05$.

Chemicals. Cocaine hydrochloride, picrotoxin, CNQX, DHF, and all other common chemicals were obtained from Sigma-Aldrich. D-AP5, BDNF, DHPG, cyclotraxin B (CTX-B), 7-(hydroxyimino)cyclopropa $[b]$ chromen-1acarboxylate ethyl ester (CPCCOEt), 2-methyl6-(phenylethynyl)pyridine hydrochloride (MPEP hydrochloride), and TTX were obtained from Tocris Bioscience.

\section{Results \\ TrkB receptor agonists facilitated eCB-mediated DSI and I-LTD}

Depolarization of hippocampal and cerebellar neurons induces transient suppression of inhibition (DSI) and excitation (DSE), which are mediated by $\mathrm{CB}_{1}$ receptors (Kreitzer and Regehr, 2001; OhnoShosaku et al., 2001; Wilson and Nicoll, 2001). We determined whether DSI could be induced in mouse VTA dopamine neurons and whether BDNF altered DSI induction. Midbrain slices were prepared from C57BL/6J mice, and whole-cell voltage-clamp recordings were made from VTA dopamine neurons. IPSCs were evoked by electrical stimulation of synaptic afferents in the presence of glutamate receptor antagonists CNQX $(20 \mu \mathrm{M})$ and D-AP-5 $(50 \mu \mathrm{M})$. We found that depolarization of dopamine neurons from -70 to $0 \mathrm{mV}$ for $5 \mathrm{~s}$ did not induce significant depression of IPSCs. Following $10 \mathrm{~min}$ perfusion of BDNF $(20 \mathrm{ng} / \mathrm{ml})$, robust DSI was induced (vehicle, $3.9 \pm$ $6.0 \%, n=9$; BDNF, $29.7 \pm 6.3 \%, n=8$; Student's $t$ test, $t_{(15)}=$ $2.97, p=0.01$; Fig. $1 A, B)$. Similarly, TrkB receptor agonist DHF $(10 \mu \mathrm{M})$ (Jang et al., 2010) enabled DSI in VTA dopamine neurons (vehicle, $2.7 \pm 5.1 \%, n=10$; DHF, $32.3 \pm 6.2 \%, n=11$, $t_{(19)}=3.64, p=0.002$; Fig. $\left.1 C, D\right)$. DSI induced in DHF was blocked by the $\mathrm{CB}_{1}$ receptor antagonist AM251 $(2 \mu \mathrm{M} ; 2.2 \pm$ $2.8 \%, n=9 ; t_{(18)}=4.12, p<0.001$ vs $\left.\mathrm{DHF}\right)$, the TrkB receptor inhibitor K252a $\left(200 \mathrm{nM} ; 3.8 \pm 4.2 \%, n=9 ; t_{(18)}=3.64, p=\right.$ 0.002 vs DHF; Fig. $1 D$ ), or the TrkB receptor antagonist CTX-B $\left(100 \mathrm{nM} ; 3.0 \pm 6.7 \%, n=12 ; t_{(21)}=3.18, p=0.004\right.$ vs DHF). Thus, BDNF and DHF enabled DSI in VTA dopamine neurons via activation of the TrkB receptor.

The $\mathrm{CB}_{1}$ receptor also mediates LTD at excitatory and inhibitory synapses (I-LTD) (Gerdeman et al., 2002; Chevaleyre and Castillo, 2003; Safo and Regehr, 2005). We next determined whether TrkB agonists affected I-LTD in VTA dopamine neurons. Repeated synaptic stimulation $(10 \mathrm{~Hz}$ stimulation for 5 
min) did not induce significant depression of IPSCs $(90.7 \pm 6.1 \%$ of baseline, $n=9 ; t_{(16)}=1.30, p=0.21$; Fig. $\left.2 A\right)$, suggesting that this stimulation is subthreshold for I-LTD induction. However, the presence of BDNF $(20 \mathrm{ng} / \mathrm{ml} ; 64.7 \pm$ $7.5 \%$ of baseline, $n=7 ; t_{(12)}=2.72, p=$ 0.002 ; Fig. $2 B$ ) or TrkB agonist DHF (10 $\mu \mathrm{M} ; 63.8 \pm 8.5 \%$ of baseline, $n=9 ; t_{(16)}=$ 3.42, $p=0.004$; Fig. $2 C$ ) enabled the $10 \mathrm{~Hz}$ stimulation to induce I-LTD. Bath application of BDNF $(20 \mathrm{ng} / \mathrm{ml} ; 91.8 \pm 6.9 \%$ of baseline, $n=6$; $t_{(10)}=0.96, p=0.36$ ) or DHF $(10 \mu \mathrm{M} ; 88.6 \pm 9.1 \%$ of baseline, $n=$ $\left.7 ; t_{(12)}=1.15, p=0.27\right)$ in the absence of the $10 \mathrm{~Hz}$ stimulation had no significant effects on basal IPSCs (Fig. 2D). Thus, BDNF and DHF enabled previously subthreshold stimulation to induce I-LTD. I-LTD induced in the presence of BDNF was blocked by the $\mathrm{CB}_{1}$ receptor antagonist AM251 (2 $\mu \mathrm{M} ; 88.8 \pm 5.7 \%$ of baseline, $\left.n=7 ; t_{(12)}=2.58, p=0.024\right)$ or by TrkB receptor inhibitor K252a (200 nM; $92.5 \pm 6.3 \%$ of baseline, $n=6 ; t_{(11)}=$ $2.79, p=0.018$; Fig. $2 E$ ). Similarly, I-LTD induced in the presence of DHF was blocked by AM251 $(2 \mu \mathrm{M} ; 90.9 \pm 6.9 \%$ of baseline, $\left.n=8 ; t_{(15)}=2.42, p=0.028\right)$ or K252a (200 nM; $89.2 \pm 7.2 \%$ of baseline, $n=8 ; t_{(15)}=2.25, p=0.04$; Fig. $\left.2 F\right)$. Together, these results indicate that BDNF and DHF facilitated eCB-mediated DSI and I-LTD in VTA dopamine neurons via activation of the TrkB receptor.

\section{Signaling mechanisms for TrkB receptor agonist-induced facilitation of eCB-mediated synaptic depression}

Activation of $\mathrm{G}_{\mathrm{q} / 11}$-coupled receptors, such as Group I metabotropic glutamate receptors (mGluRs), enhances DSI (Varma et al., 2001; Edwards et al., 2006) through an increase in the production of $\mathrm{eCB}$ ligand 2-AG (Maejima et al., 2001; Varma et al., 2001; Jung et al., 2005). Activation of Group I mGluRs is required for I-LTD in the hippocampus (Chevaleyre and Castillo, 2003) and VTA (Pan et al., 2008a, b). Group I mGluRs are positively coupled to phospholipase $\mathrm{C} \beta$ (PLC $\beta$ ), which cleaves phosphatidylinositol 1,4,5-bisphosphate (PIP2) into diacylglycerol (DAG) and inositol 1,4,5-trisphosphate (IP3), and DAG is subsequently converted into 2-AG by DAG lipase (Di Marzo et al., 1998; Piomelli, 2003). The binding of BDNF to TrkB receptors stimulates PLC $\gamma$, which cleaves PIP2 into IP3 and DAG (Reichardt, 2006). BDNF and DHF might facilitate eCB-mediated synaptic depression via enhancement of $2-A G$ production. To test this possibility, we examined whether
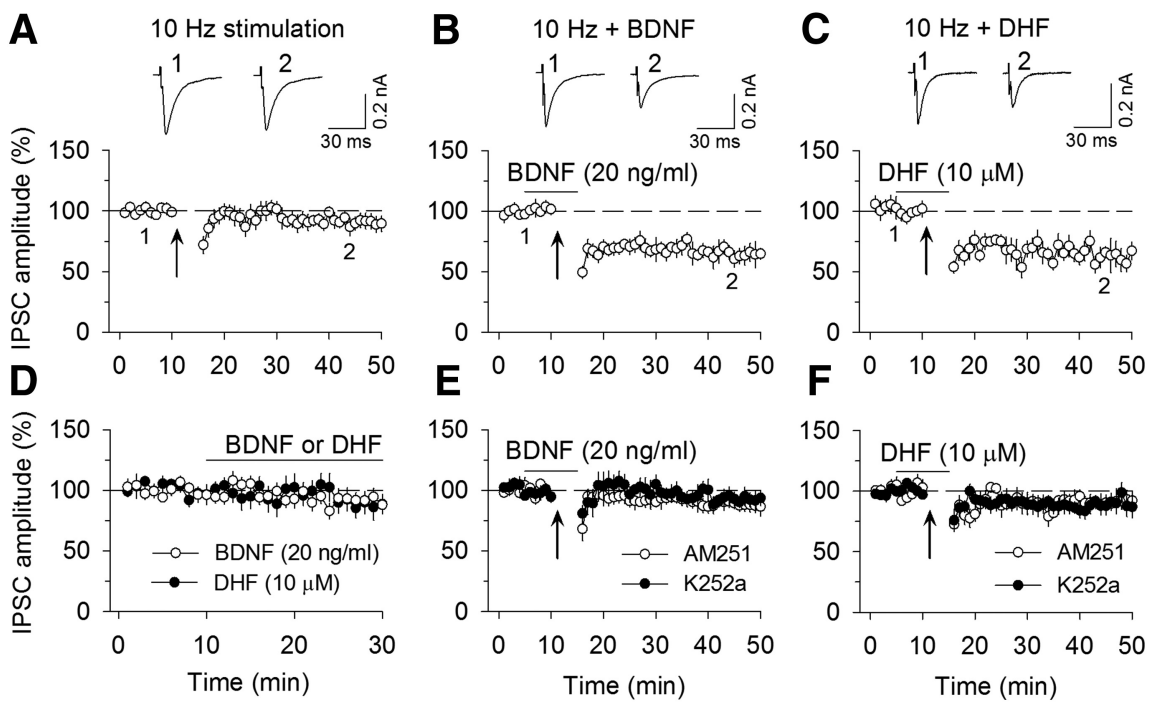

Figure 2. TrkB receptor agonists enabled I-LTD induction in VTA dopamine neurons. $\boldsymbol{A}$, The $10 \mathrm{~Hz}, 5$ min stimulation (indicated by arrow) did not induce I-LTD $(n=9 ; p>0.05) . \boldsymbol{B}, \boldsymbol{C}$, The presence of BDNF $(20 \mathrm{ng} / \mathrm{ml} ; n=7 ; p<0.01 ; \boldsymbol{B})$ or DHF $(10 \mu \mathrm{m} ; n=$ $9 ; p<0.01 ; C)$ before and during the $10 \mathrm{~Hz}$ stimulation led to I-LTD induction. $\boldsymbol{D}$, Bath application of BDNF $(20 \mathrm{ng} / \mathrm{ml} ; n=6 ; p>$ 0.05) or DHF (10 $\mu \mathrm{m} ; n=7 ; p>0.05)$ in the absence of the $10 \mathrm{~Hz}$ stimulation had no significant effects on basal IPSCs. E, I-LTD induced in the presence of BDNF was blocked by the $\mathrm{CB}_{1}$ receptor antagonist $\mathrm{AM} 251(2 \mu \mathrm{M} ; n=7 ; p<0.05)$ or by TrkB receptor inhibitor K252a $(200 \mathrm{~nm} ; n=6 ; p<0.05)$. $\boldsymbol{F}$, I-LTD induced in the presence of DHF was blocked by AM251 $(n=8 ; p<0.05)$ or $\mathrm{K} 252 \mathrm{a}(n=8 ; p<0.05)$.

\section{A}

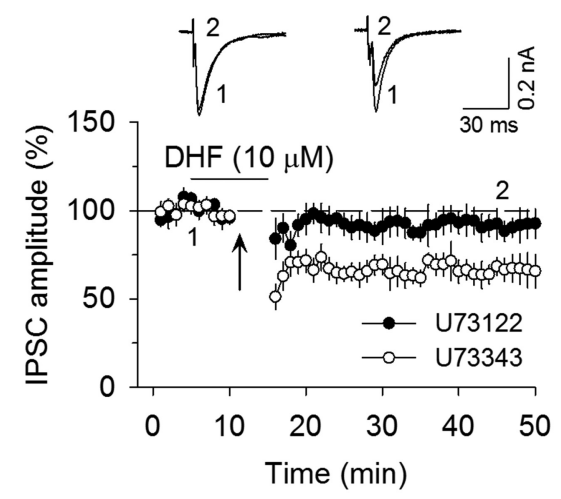

C

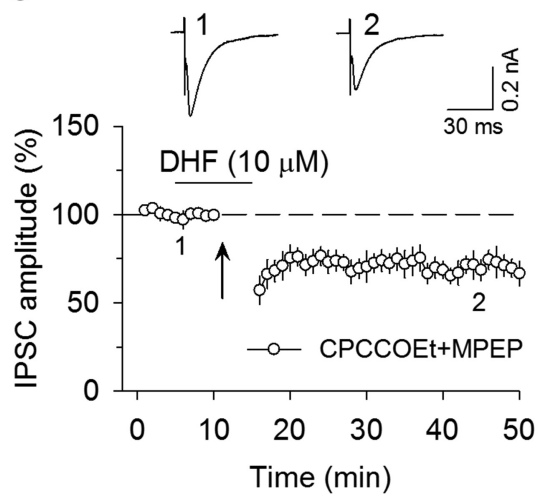

B $\quad$ RHC-80267 THL

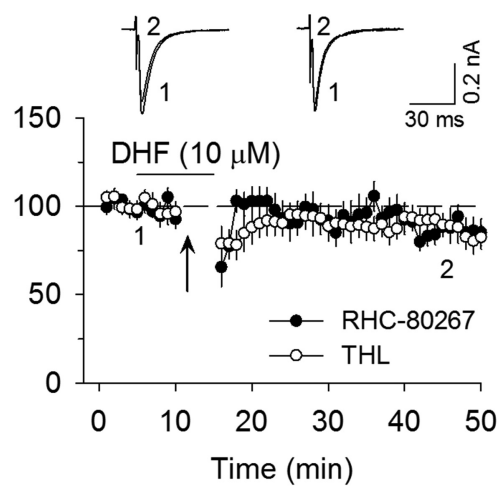

D
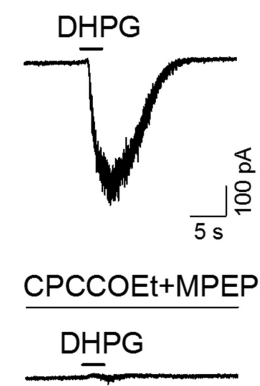

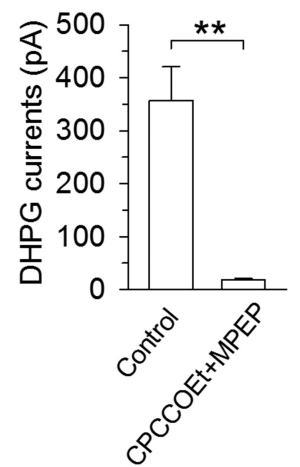

Figure 3. DHF-facilitated I-LTD was blocked by PLC and DAG lipase inhibitors. $\boldsymbol{A}$, The PLC inhibitor U73122 (5 $\mu \mathrm{m})$ blocked I-LTD induced in the presence of DHF $(n=9 ; p<0.05)$, whereas the inactive analog U73343 $(5 \mu \mathrm{M})$ did not significantly alter I-LTD $(n=7 ; p>0.05)$. $\boldsymbol{B}$, DAG lipase inhibitors RHC-80267 $(n=9 ; p<0.05)$ and THL $(n=8 ; p<0.05)$ significantly attenuated I-LTD. C, Coapplication of mGluR1 antagonist CPCCOEt ( $80 \mu \mathrm{M})$ and mGluR5 antagonist MPEP (10 $\mu \mathrm{M})$ did not significantly affect I-LTD $(n=8 ; p>0.05)$. Arrows indicate the application of a $10 \mathrm{~Hz}, 5 \mathrm{~min}$ stimulation. $\boldsymbol{D}$, Application of CPCCOEt $(80 \mu \mathrm{M})$ and MPEP $(10 \mu \mathrm{M})$ blocked the inward current induced by pressure injection of DHPG (10 $\mu \mathrm{M})$ via a patch pipette $\left(n=6{ }^{* *} p<0.01\right)$. 
A

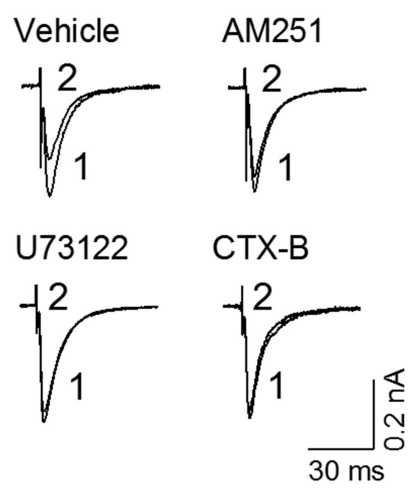

B

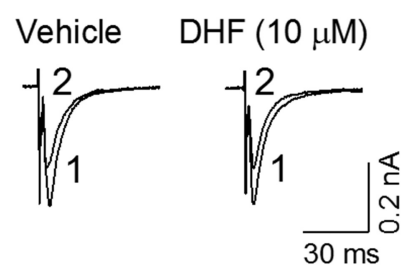

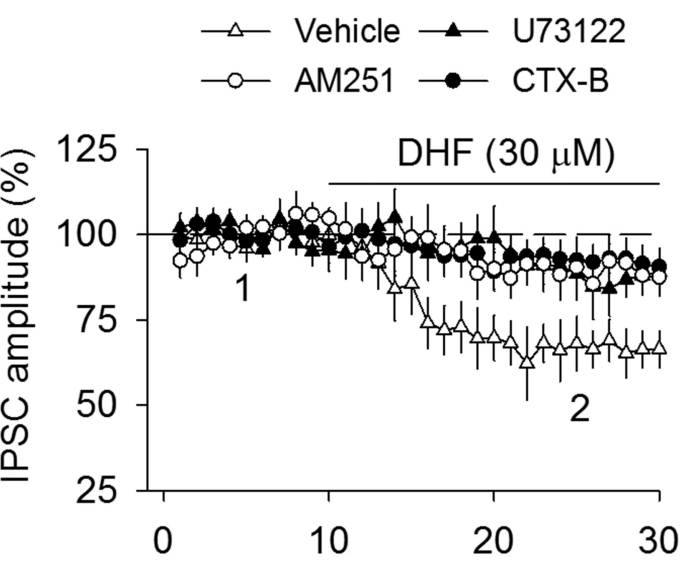
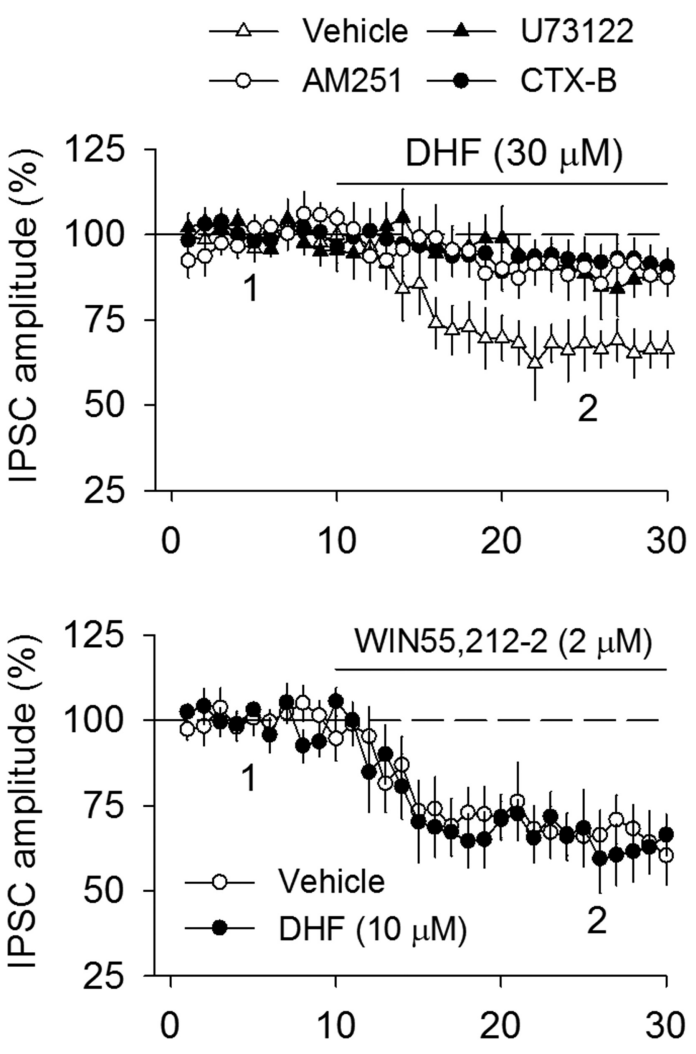

C

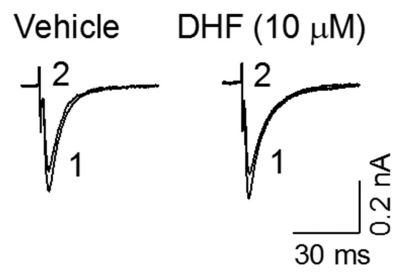

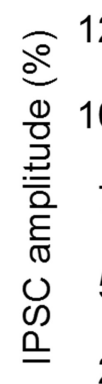

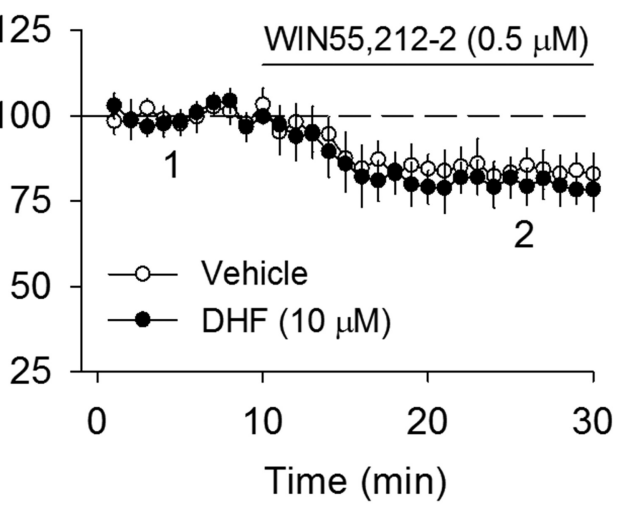

Figure 4. DHF at a higher concentration depressed IPSCs via a TrkB- and $C_{1}$ receptor-dependent mechanism. $A$, Bath application of DHF $(30 \mu \mathrm{M})$ significantly decreased the amplitude of IPSCs $(n=8)$, and this depression was abolished by the continuous presence of the TrkB receptor antagonist CTX-B $(100 \mathrm{~nm} ; n=8 ; p<0.01), \mathrm{CB}_{1}$ receptor antagonist AM251 $(2 \mu \mathrm{m} ; n=8 ; p<$ 0.05), or PLC inhibitor U73122 (5 $\mu \mathrm{m} ; n=7 ; p<0.05$ ). B, C, Bath application of $C_{1}$ receptor agonist WIN 55212-2 at $2 \mu \mathrm{M}(\boldsymbol{B})$ and $0.5 \mu \mathrm{M}(\boldsymbol{C})$ decreased the amplitude of IPSCS ( $n=8$ each group), whereas the continuous presence of DHF (10 $\mu \mathrm{m})$ had no significant effect on this depression ( $n=8$ or $9 ; p>0.05$ ).

selective membrane-permeable broad-spectrum PLC inhibitor U73122 affected I-LTD induction. The inactive analog U73343 was served as a negative control. Slices were treated with U73122 $(5 \mu \mathrm{M})$ or U73343 (5 $\mu \mathrm{M})$ for $\geq 1 \mathrm{~h}$; U73122 or U73343 was also bath applied throughout the experiment (Chevaleyre and Castillo, 2003; Edwards et al., 2006). As shown in Figure 3A, I-LTD induced in the presence of DHF $(10 \mu \mathrm{M})$ was blocked by U73122 (91.8 $\pm 7.7 \%$ of baseline, $n=9 ; t_{(16)}=2.44, p=0.027$ vs I-LTD control in Fig. 2C) but was not significantly affected by the inactive analog U73343 (65.9 $\pm 7.2 \%$ of baseline, $n=7 ; t_{(14)}=0.18$, $p=0.86$ vs I-LTD control). Next, we examined whether DAG lipase inhibitors RHC-80267 and tetrahydrolipstatin (THL) affected I-LTD. RHC-80267 (30 $\mu \mathrm{M})$ or THL $(10 \mu \mathrm{M})$ was bath applied throughout the experiment. Figure $3 B$ shows that both RHC-80267 and THL significantly attenuated I-LTD (RHC-80267, $87.5 \pm 6.0 \%$ of baseline, $n=9 ; t_{(16)}=2.27, p=0.037$ vs I-LTD control; THL, $88.2 \pm 7.0 \%$ of baseline, $n=8 ; t_{(15)}=2.18, p=0.046$ vs I-LTD control). These results suggest that DHF facilitated I-LTD by activating the PLC/ DAG lipase pathway.

Currently available PLC inhibitors, such as U73122, cannot discriminate between PLC $\beta$ and PLC $\gamma$. There is a possibility that the $\operatorname{TrkB}$ receptor agonists enhance the release of glutamate, which then activates the mGluR/PLC $\beta$ pathway to enhance I-LTD. We examined whether Group I mGluR antagonism affected the facilitation of DHF on I-LTD. Bath application of mGluR1 antagonist CPCCOEt $(80 \mu \mathrm{M})$ and mGluR5 antagonist MPEP $(10 \mu \mathrm{M})$ did not significantly affect I-LTD induced in the presence of DHF (69.8 \pm $6.2 \%$ of baseline, $n=8 ; t_{(15)}=0.56, p=$ 0.58 vs I-LTD control; Fig. $3 C$ ). Rapid application of Group I mGluR agonist DHPG induced an inward current in many neuronal cell types, including midbrain dopamine neurons; this current was mediated by the activation of transient receptor potential-like channels (Kim et al., 2003; Tozzi et al., 2003; Gong et al., 2011). As a positive control, we examined the effect of CPCCOEt and MPEP on the DHPG-induced inward current in the VTA. We found that a brief pressure injection $(3 s)$ of DHPG $(10 \mu \mathrm{M})$ via a patch pipette induced robust inward currents in all VTA dopamine neurons tested $(357.5 \pm 63.3 \mathrm{pA}, n=6)$. Bath application of CPCCOEt $(80 \mu \mathrm{M})$ and MPEP $(10 \mu \mathrm{M})$ rapidly abolished (within $10 \mathrm{~min}$ ) the DHPG-induced currents $(17.7 \pm 2.9 \mathrm{pA}$, $n=6 ; t_{(5)}=5.60 ; p=0.003$; Fig. $\left.3 D\right)$. Thus, CPCCOEt and MPEP were effective in blocking Group I mGluR-mediated currents in the VTA. The finding that CPCCOEt and MPEP did not alter DHF-enabled I-LTD suggests that Group I mGluRs are not involved in DHF-induced facilitation of I-LTD.

We examined whether a higher concentration of DHF (30 $\mu \mathrm{M})$ affected basal IPSCs in VTA dopamine neurons. Bath application of DHF (30 $\mu \mathrm{M})$ for 20 min induced significant depression of evoked IPSCs ( $66.6 \pm 5.8 \%$ of baseline, $n=8 ; t_{(14)}=4.88, p<$ 0.001 ), whereas this depression was significantly attenuated by the TrkB receptor antagonist CTX-B (100 nM; $91.9 \pm 5.3 \%$ of baseline, $n=8 ; t_{(14)}=3.20, p=0.006$ vs control), the $\mathrm{CB}_{1}$ receptor antagonist AM251 ( $2 \mu \mathrm{M} ; 89.0 \pm 6.0 \%$ of baseline, $n=$ $8 ; t_{(14)}=2.67, p=0.018$ vs control), or PLC inhibitor U73122 (5 $\mu \mathrm{M} ; 86.5 \pm 7.1 \%$ of baseline, $n=7 ; t_{(13)}=2.18, p=0.048$ vs control; Fig. 4A). These results suggest that DHF at a higher concentration depresses IPSCs via a TrkB- and $\mathrm{CB}_{1}$ receptordependent mechanism. 
2-AG is hydrolyzed primarily by monoacylglycerol lipase (MAGL) (Cravatt et al., 1996; Blankman et al., 2007). Incubation of BDNF for 4-24 h increases the expression of $\mathrm{CB}_{1}$ receptor transcripts and decreases expression of MAGL transcripts in cultured cerebellar granule neurons (Maison et al., 2009). It is thus possible that BDNF and DHF facilitated DSI and I-LTD by enhancing $\mathrm{CB}_{1}$ receptor responsiveness or decreasing MAGL activity. We have shown that bath application of $\mathrm{CB}_{1}$ receptor agonist WIN55212-2 induced depression of IPSCs in VTA dopamine neurons (Pan et al., 2008b). An increase in $\mathrm{CB}_{1}$ receptor expression and function would enhance the depression of IPSCs induced by exogenous $\mathrm{CB}_{1}$ receptor agonists. However, we found that DHF $(10 \mu \mathrm{M})$ had no significant effects on the depression of IPSCs induced by WIN 55212-2 at a submaximal concentration $(2 \mu \mathrm{M})$ (vehicle, $65.9 \pm 7.8 \%$ of baseline, $n=8$; DHF, $62.1 \pm 8.1 \%$ of baseline, $n=$ $9 ; t_{(15)}=0.34, p=0.74$; Fig. $4 B$ ) and at a lower concentration $(0.5 \mu \mathrm{M})$ (vehicle, $83.9 \pm 5.4 \%$ of baseline, $n=8$; DHF, $79.4 \pm 5.5 \%$ of baseline, $n=8 ; t_{(14)}=$ $0.58, p=0.57$; Fig. $4 C$ ), suggesting that, under the present experimental conditions, DHF does not significantly alter $\mathrm{CB}_{1}$ receptor responsiveness.

To test the possibility that BDNF and DHF facilitated DSI and I-LTD by decreasing MAGL activity, we compared the time course of DSI induced in the presence of Group I mGluR agonist DHPG, MAGL inhibitor JZL184, and TrkB agonists BDNF and DHF. We have shown that MAGL inhibitor JZL184 significantly prolongs the decay time constant of DSI in the hippocampal neurons (Pan et al., 2009). DHPG is known to enhance DSI by increasing 2-AG synthesis (Jung et al., 2005; Edwards et al., 2006). We obtained the decay time constant $(\tau)$ and magnitude of DSI induced in the presence of either BDNF or DHF from Figure 1 ( $\tau$ : BDNF, $7.2 \pm$ $1.5 \mathrm{~s}, n=8$; DHF, $7.5 \pm 1.8 \mathrm{~s}, n=11)$ and found that $\tau$ of DSI from either group was not significantly different from that of DHPG ( $1 \mu \mathrm{M}$; DHPG, $7.1 \pm 1.7 \mathrm{~s}, n=14 ; t_{(20)}=0.059, p=0.95$ vs BDNF group; $t_{(23)}=0.17, p=0.87$ vs DHF group; Fig. $5 \mathrm{~A}, \mathrm{C}$ ) but was significantly less than that of JZL184 (100 nM; JZL184, $14.7 \pm 2.3 \mathrm{~s}, n=11 ; t_{(17)}=2.48, p=0.024 \mathrm{vs}$ BDNF; $t_{(20)}=2.41$, $p=0.026$ vs DHF; Fig. $5 B, C)$. There was no significant difference of the magnitude of DSI induced in the presence of BDNF, DHF, DHPG, and JZL184 (DHPG, $28.5 \pm 4.8 \%, n=11$; JZL184, $32.9 \pm 6.3 \%, n=11$; Fig. $5 D$ ). DSI induced in the presence of DHPG and JZL184 was blocked by AM251 $(2 \mu \mathrm{M}$; DHPG + AM251, $4.0 \pm 3.2 \%, n=9 ; t_{(18)}=4.06, p<0.001$ vs DHPG; $\mathrm{JZL1} 184+\mathrm{AM} 251,3.5 \pm 5.5 \%, n=8 ; t_{(17)}=3.36, p=0.004 \mathrm{vs}$ JZL184). BDNF is coupled to PLC $\gamma$ pathway, which cleaves PIP2 into IP3 and DAG (Reichardt, 2006). DAG is a precursor of eCB Iigand 2-AG (Di Marzo et al., 1998; Piomelli, 2003). BDNF is therefore linked to 2-AG-synthesizing machinery. Comparing the time course of DSI, it is apparent that BDNF and DHF behave
B

Vehicle JZL184
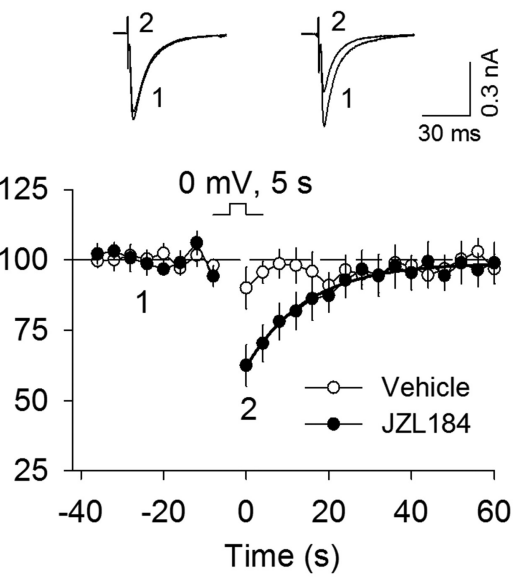

D

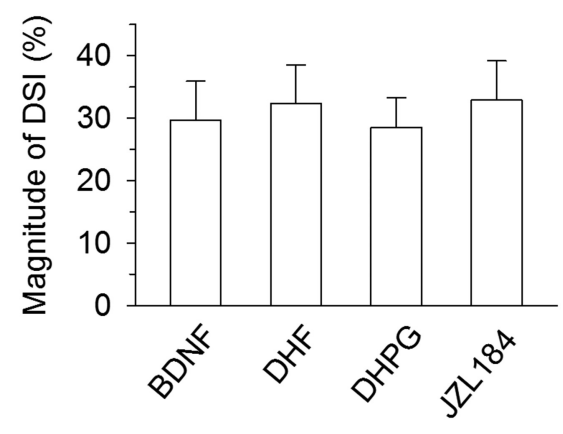

Figure 5. Time course comparison of DSI implies that BDNF and DHF enable DSI via an increase in 2-AG production but not via 2-AG hydrolysis. $A, B$, DSI was induced in VTA dopamine neurons in the continuous presence of Group I mGluR agonis $(p>0.05)$ but was significantly less than that of the JZL184 group $\left({ }^{*} p<0.05\right)$. $\boldsymbol{D}$, There was no significant difference in the magnitude of DSI induced in the presence of BDNF, DHF, DHPG, and JZL184 ( $p>0.05)$.

like DHPG, which increases 2-AG synthesis (Jung et al., 2005), but not like JZL184, which inhibits 2-AG hydrolysis (Long et al., 2009). It is thus likely that BDNF and DHF enhance DSI via an increase in 2-AG synthesis rather than a reduction of 2-AG hydrolysis.

\section{Effects of conditional knock-out of BDNF in dopamine neurons on I-LTD}

To test the role of endogenous BDNF in I-LTD, we used Cre-loxP technology to selectively delete BDNF from dopamine neurons and examined its impact on I-LTD. We used DAT-Cre $e^{+/-}$mice that express Cre recombinase controlled by dopamine transporter (DAT) promoter (Bäckman et al., 2006). To examine the effectiveness and specificity of Cre recombinase in DAT-Cre ${ }^{+/-}$ mice, we crossed this mouse line with ROSA26 LacZ reporter mice. Cre recombinase was selectively expressed in the midbrain dopamine neurons as shown by colocalization of $\beta$-gal with dopamine synthetic enzyme and dopamine cell marker tyrosine hydroxylase (TH) (Fig. 6A,B). These results confirm the effectiveness and specificity of the expression of Cre recombinase in DAT-Cre ${ }^{+/-}$mice.

We generated dopamine neuron-specific BDNF knock-out mice by crossing homozygous $B d n f^{\text {doxP/loxP }}$ mice with heterozygous DAT-Cre $e^{+/-}$mice. Among the offspring generated, $D A T-C r e^{+/-} / B d n f^{\text {foxP/loxP }}$ mice were used as BDNF cKO group. 
A
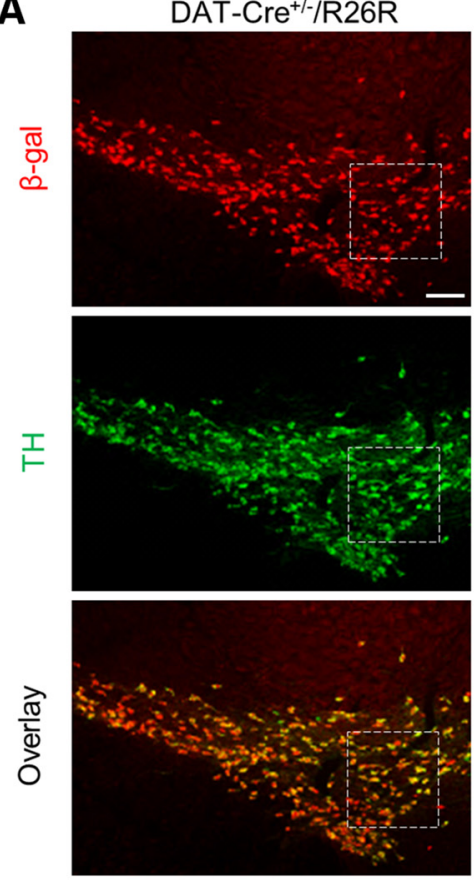

C

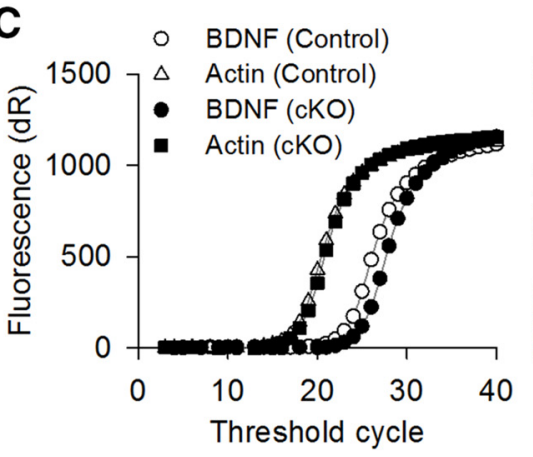

Figure 6. Generation of dopamine neuron-specific BDNF CKO mice. $\boldsymbol{A}, \boldsymbol{B}$, Cre recombinase was expressed in midbrain dopamine neurons in the offspring (DAT-Cre $\left.{ }^{+/-} / R 26 R\right)$ of DAT$\mathrm{Cre}^{+/-}$mice crossed with $R 26 R$ lacZ reporter mice. Immunofluorescence staining of midbrain sections showed that $\beta$-galactosidase (red) was exclusively expressed in $\mathrm{TH}^{+}$(green) dopamine neurons in DAT-Cre $\left.{ }^{+/-[r}\right] / R 26 R$ mice $(\boldsymbol{A}) . n=3$ mice. High-power view of the dashed boxes in $\boldsymbol{A}$ showed colocalization of $\beta$-galactosidase and TH (B). Scale bar, $100 \mu \mathrm{m}$. C, D, BDNF cKO mice were generated by crossing $B d n f^{\text {oxP } / \text { lox } P}$ mice with DAT-Cre ${ }^{+/-}$mice. Representative amplification curves for BDNF and $\beta$-actin mRNA from individual mouse VTA sample $(\boldsymbol{C})$ and summarized data $(\boldsymbol{D})$ of real-time quantitative $P C R$ indicated that BDNF mRNA level in the VTA of BDNFCKO(DAT-Cre $\left.e^{+/-} / B d n f^{\text {doxP/loxP }}\right)$ mice was significantly decreased compared with that in wild-type control (DAT-Cre ${ }^{-/-} /$Bdnf $f^{\text {oxP/loxP }}$ and DAT-Cre $\left.{ }^{-/-} / B D N F^{\text {IoxP/wt }}\right)$ mice $\left(^{*} p<0.05\right)$.

$D A T-C r e^{-/-} / B d n f^{\text {foxP/loxP }}$ and DAT-Cre $e^{-/-} / B D N F^{\text {loxP/wt }}$ mice were used as wild-type control groups. Real-time quantitative PCR indicates that the BDNF mRNA level in the VTA of BDNF cKO mice was significantly decreased compared with that in wild-type control mice $\left(t_{(8)}=3.21, p=0.012\right.$; Fig. $\left.6 C, D\right)$. These data confirmed the effectiveness of BDNF deletion under the present experimental conditions.

We have shown that a pathophysiologically relevant concentration of cocaine $(3 \mu \mathrm{M})$ enabled subthreshold stimulation (10 $\mathrm{Hz}, 5 \mathrm{~min}$ ) to induce I-LTD in rat VTA dopamine neurons, and this I-LTD was blocked by $\mathrm{CB}_{1}$ receptor antagonists (Pan et al., $2008 \mathrm{a}, \mathrm{b})$. We examined whether endogenous BDNF is required for this form of I-LTD. Repeated synaptic stimulation $(10 \mathrm{~Hz}, 5$ min) did not induce significant depression of IPSCs in either wild-type control mice $\left(89.1 \pm 6.6 \%\right.$ of baseline, $n=7 ; t_{(12)}=$
$1.40, p=0.19)$ or $B D N F c K O$ mice $(91.8 \pm 6.2 \%$ of baseline, $n=$ $6 ; t_{(10)}=1.11, p=0.29$; Fig. $\left.7 A\right)$. The presence of cocaine $(3 \mu \mathrm{M})$ during $10 \mathrm{~Hz}$ stimulation enabled I-LTD in wild-type control mice $\left(63.0 \pm 8.6 \%\right.$ of baseline, $n=7 ; t_{(12)}=2.40, p=0.033 \mathrm{vs}$ control) but did not induce significant depression of IPSCs in BDNF cKO mice $\left(92.8 \pm 7.6 \%\right.$ of baseline, $n=8 ; t_{(12)}=0.10, p=$ 0.92 vs control; Fig. $7 B$ ). This I-LTD was blocked by the $\mathrm{CB}_{1}$ receptor antagonist AM251 $(2 \mu \mathrm{M} ; 89.7 \pm 7.8 \%$ of baseline, $n=$ $7 ; t_{(12)}=2.29, p=0.041$ vs I-LTD control). Next, we determined whether TrkB agonist DHF could rescue I-LTD in BDNF $c K O$ mice. In the presence of cocaine $(3 \mu \mathrm{M})$ plus DHF $(10 \mu \mathrm{M})$, robust I-LTD was induced in BDNF $c K O$ mice $(68.4 \pm 7.7 \%$ of baseline, $\left.n=8 ; t_{(14)}=3.43, p=0.004\right)$, and this I-LTD was blocked by AM251 $\left(2 \mu \mathrm{M} ; 93.8 \pm 7.8 \%\right.$ of baseline, $n=7 ; t_{(13)}=2.24, p=$ 0.043 vs I-LTD in BDNF cKO mice; Fig. $7 C)$. Thus, DHF rescued I-LTD in VTA dopamine neurons in BDNF $c K O$ mice. In wildtype control mice, the presence of DHF and cocaine did not significantly increase the magnitude of I-LTD compared with that induced by cocaine alone $(63.4 \pm 8.0 \%$ of baseline, $n=6$; $t_{(11)}=0.033, p=0.97$ vs I-LTD control in Fig. $\left.7 B, D\right)$, suggesting that endogenous BDNF is sufficient to support I-LTD.

\section{BNDF is required for cocaine-induced inhibitory synaptic plasticity}

We have shown that daily intraperitoneal injections of cocaine to rats for 5-7 d reduces the mean amplitude of maximal IPSCs and miniature IPSCs (mIPSCs) in VTA dopamine neurons of midbrain slices, indicating that repeated cocaine exposure in vivo reduces the strength of GABAergic inhibition to VTA dopamine neurons (Liu et al., 2005). Our previous studies suggest that repeated cocaine exposure in vivo reduces the strength of GABAergic inhibition onto dopamine neurons by inducing an I-LTD-like synaptic plasticity (Pan et al., 2008b). Having shown that BDNF is required for I-LTD induction in VTA dopamine neurons, we next determined whether cocaine-induced reduction of GABAergic inhibition was altered by dopamine neuronspecific deletion of BDNF. Wild-type control and BDNF $c K O$ mice were given intraperitoneal injections of saline or cocaine (15 $\mathrm{mg} / \mathrm{kg}$ ) for $5 \mathrm{~d}$. Midbrain slices were prepared from these four groups of mice the next day, maximal IPSCs and mIPSCs were recorded as described in Materials and Methods. Maximal IPSCs were elicited by gradually increasing the stimulation intensity to recruit saturating IPSCs (Huang et al., 1999; Liu et al., 2005), which yield a good estimate of total inhibitory inputs to the recorded neuron. mIPSCs recorded in the presence of TTX $(0.5 \mu \mathrm{MM})$ represent quantal GABA release from presynaptic axonal terminals (Zhu and Lovinger, 2005). Together, maximal IPSCs and mIPSCs provide a good indication of the strength of GABAergic inhibition. We found that cocaine treatment and genotype had significant effects on the mean amplitude of maximal IPSCs (cocaine: $F_{(1,39)}=$ 6.27, $p=0.017$; genotype: $F_{(1,39)}=4.23, p=0.046$; cocaine $\times$ genotype interaction: $F_{(1,39)}=6.89, p=0.012$; Fig. $8 A$ ) and mIPSCs (cocaine: $F_{(1,43)}=9.45, p=0.004$; genotype: $F_{(1,43)}=$ $11.12, p=0.002$; cocaine $\times$ genotype interaction: $F_{(1,43)}=4.55$, $p=0.039$; Fig. $8 B$ ). Tukey's post hoc test indicated that the mean amplitude of maximal IPSCs $(p=0.001)$ and mIPSCs $(p<$ 0.001 ) was significantly decreased in cocaine-treated wild-type control mice compared with saline-treated wild-type control mice. BDNF cKO had no significant effects on the mean amplitude of maximal IPSCs $(p=0.69)$ and mIPSCs $(p=0.41)$ in saline-injected groups but blocked the decreases in the mean amplitude of maximal IPSCs $(p=0.93)$ or mIPSCs $(p=0.51)$ in cocaine-injected groups. These results suggest that cocaine- 
induced reduction of GABAergic inhibition was blocked in BDNF conditional knock-out mice.

A consequence of cocaine-induced reduction of GABAergic inhibition to VTA dopamine neurons is to facilitate synaptic potentiation in vivo (Liu et al., 2005). Single or repeated cocaine intraperitoneal injections increase the AMPAR/NMDAR ratio, an indicator for synaptic strength, in VTA dopamine neurons (Ungless et al., 2001; Borgland et al., 2004; Liu et al., 2005; Mameli et al., 2009). We determined whether endogenous BDNF is required for the increase in the AMPAR/NMDAR ratio in VTA dopamine neurons. Wildtype control and BDNF $c K O$ mice were given intraperitoneal injections of saline or cocaine $(15 \mathrm{mg} / \mathrm{kg}$ ) for $5 \mathrm{~d}$. Midbrain slices were prepared from these four groups of mice the next day; AMPAR/ NMDAR ratio in VTA dopamine neurons was measured as described in our previous studies (Liu et al., 2005, 2014). Two-way ANOVA showed that cocaine treatments and genotype had significant effects on the AMPAR/NMDAR ratio in VTA dopamine neurons (cocaine: $F_{(1,45)}=8.65, p=$ 0.005 ; genotype: $\left.F_{(1,45)}=4.24, p=0.045\right)$; there was a significant interaction between cocaine treatments and genotype $\left(F_{(1,45)}=10.20, p=0.003\right.$; Fig. 9$)$. Tukey's post hoc tests indicated that cocaine treatments significantly increased the AMPAR/NMDAR ratio in wild-type control mice $(p<0.001)$, whereas this increase was blocked in BDNF $c K O$ mice $(p=0.86)$. Together, the above results suggest that BDNF is required for cocaine-induced I-LTD, reduction of GABAergic inhibition, and increase in the AMPAR/NMDAR ratio in VTA dopamine neurons.

\section{BDNF conditional knock-out attenuated CPP to cocaine}

Cocaine-induced synaptic plasticity in the VTA has been implicated in the formation of drug-associated memories (Kauer, 2004). We examined the effect of dopamine neuron-specific knock-out of BDNF on cocaine-induced CPP. During the baseline preference test (pretest), six mice showing unconditioned side preference $(\geq 180 \mathrm{~s}$ disparity) were excluded. The remaining mice exhibited no significant unconditioned place preference (Fig. 10A). Then the saline $(0.9 \% \mathrm{NaCl}$, i.p.) and cocaine $(15 \mathrm{mg} / \mathrm{kg})$ place conditioning was conducted once daily for $3 \mathrm{~d}$ (see Materials and Methods). CPP was tested $24 \mathrm{~h}$ after the last place conditioning. Two-way ANOVA revealed that cocaine condition-
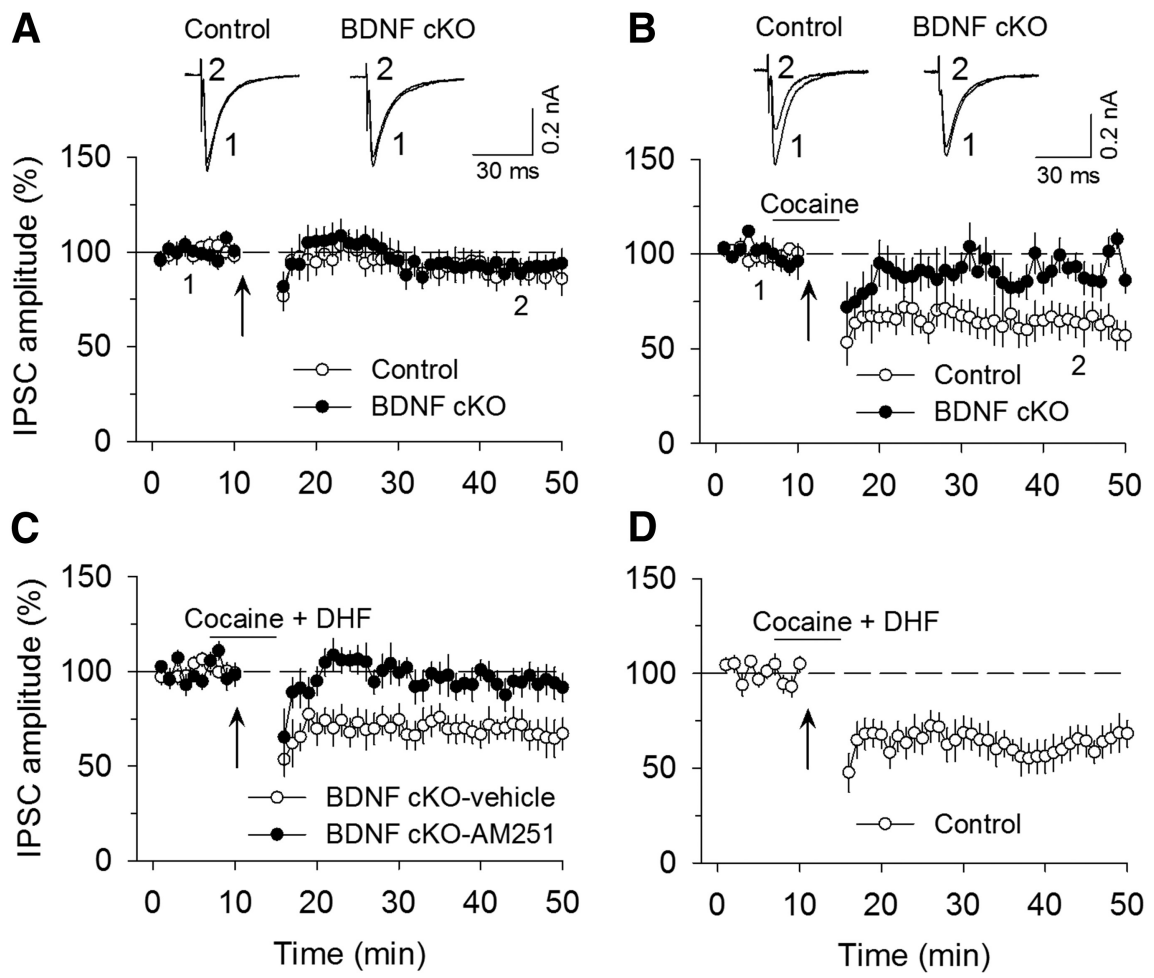

Figure 7. Endogenous BDNF is required for cocaine-induced I-LTD. $\boldsymbol{A}$, The $10 \mathrm{~Hz}, 5$ min stimulation had no significant effect on evoked IPSC in either wild-type control mice $(n=7 ; p>0.05)$ or BDNFCKO mice $(n=6 ; p>0.05)$. Sample traces of IPSC $s$ before and after the $10 \mathrm{~Hz}$ stimulation are superimposed on the top. $\boldsymbol{B}$, The presence of cocaine $(3 \mu \mathrm{m}) 3 \mathrm{~min}$ before and during the $10 \mathrm{~Hz}$ stimulation enabled I-LTD in wild-type control mice $(n=7 ; p<0.05)$ but did not induce I-LTD in BDNFcKO mice $(n=8 ; p>0.05)$. C, The presence of cocaine $(3 \mu \mathrm{m})$ and DHF $(10 \mu \mathrm{m}) 3 \mathrm{~min}$ before and during the $10 \mathrm{~Hz}$ stimulation led to I-LTD induction in BDNF cKO mice $(n=8 ; p<0.01)$, and this I-LTD was blocked by AM251 $(2 \mu \mathrm{M} ; n=7 ; p<0.05)$. $\boldsymbol{D}$, In wild-type control mice, the presence of cocaine and DHF did not significantly increase the magnitude of I-LTD compared with that induced by cocaine alone $(n=6 ; p>0.05)$. Arrows indicate the application of a $10 \mathrm{~Hz}, 5$ min stimulation.

A
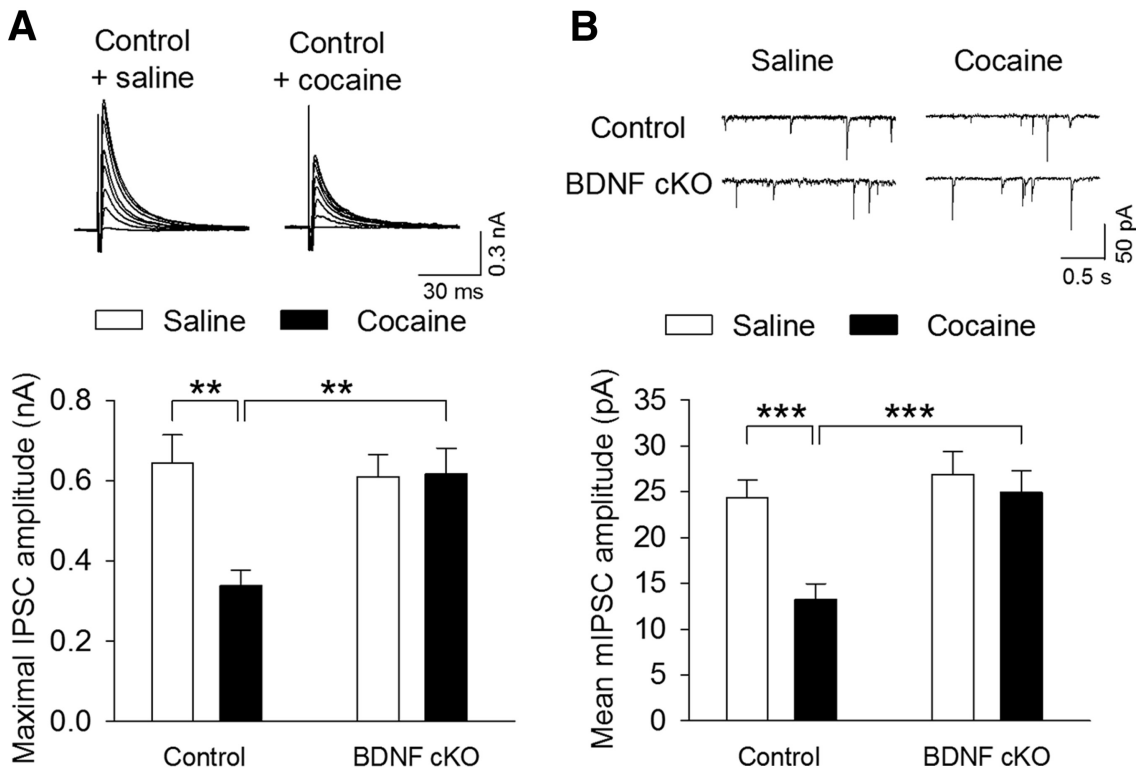

Figure 8. Endogenous BDNF is required for cocaine-induced reduction of GABAergic inhibition. Wild-type control and BDNF $C K O$ mice were given intraperitoneal injections of saline or cocaine $(15 \mathrm{mg} / \mathrm{kg})$ for $5 \mathrm{~d}$. Midbrain slices were prepared from these four groups of mice the following day. $\boldsymbol{A}$, Top, Sample IPSCs in response to stimuli of incremental intensities $(20-140 \mu \mathrm{A})$. The neurons were voltage-clamped at $-20 \mathrm{mV}$. Bottom, Summarized data showed that the mean amplitude of maximal IPSCs was significantly decreased in cocaine-treated wild-type control mice compared with saline-treated wild-type control mice $\left({ }^{* *} p<0.01\right)$. BDNF CKO had no significant effects on the mean amplitude of maximal IPSC s in saline-injected groups $(p>0.05)$ but blocked the decreases in the mean amplitude of maximal IPSCs in cocaine-injected groups $(p>0.05) . n=10$ or 11 for each group. $\boldsymbol{B}$, Same as in $\boldsymbol{A}$, except that mIPSCs were recorded at a holding potential $-70 \mathrm{mV} . n=11$ or 12 for each group. ${ }^{* * *} p<0.001$. 
A
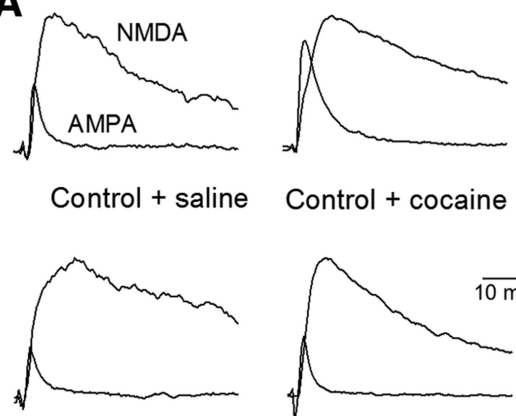

Control + cocaine

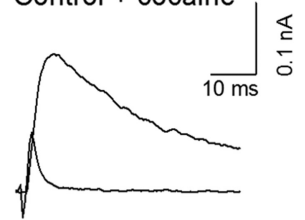

BDNF cKO + saline

BDNF cKO + cocaine
B

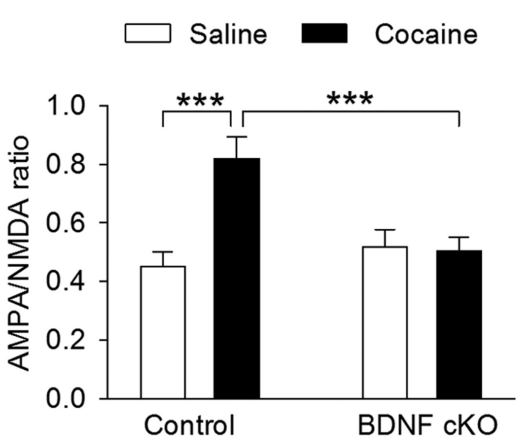

Figure 9. Endogenous BDNF is required for cocaine-induced potentiation of the AMPAR/NMDAR ratio. Wild-type control and BDNF CKO mice were given intraperitoneal injections of saline or cocaine $(15 \mathrm{mg} / \mathrm{kg})$ for $5 \mathrm{~d}$. Midbrain slices were prepared from these four groups of mice the next day. $\boldsymbol{A}$, Representative AMPAR- and NMDAR-mediated evoked EPSCs recorded from VTA dopamine neurons. $\boldsymbol{B}$, Cocaine treatments significantly increased the AMPAR/NMDAR ratio in wild-type control mice ${ }^{* * *} p<$ $0.001)$, and this increase was blocked in BDNF $C K O$ mice $(p>0.05) . n=12$ or 13 for each group.

\section{A} Saline and cocaine conditioning

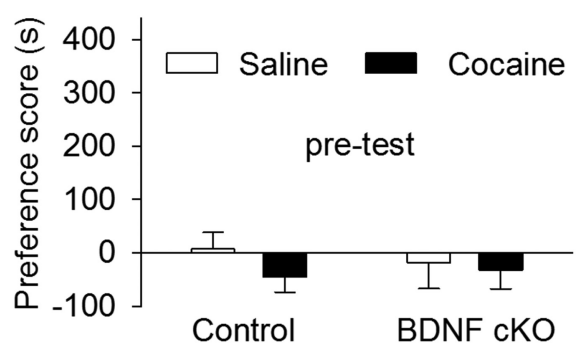

C

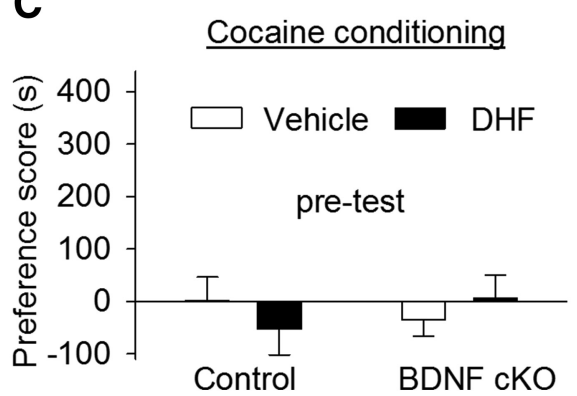

B

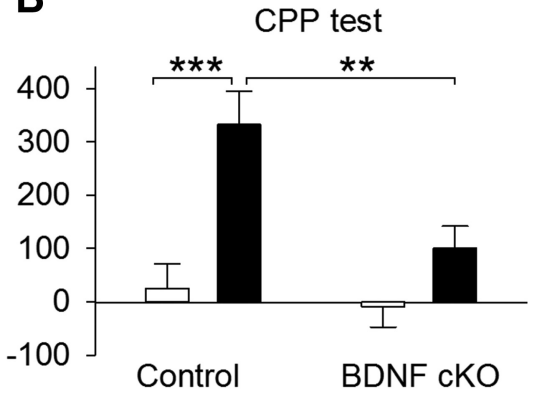

D

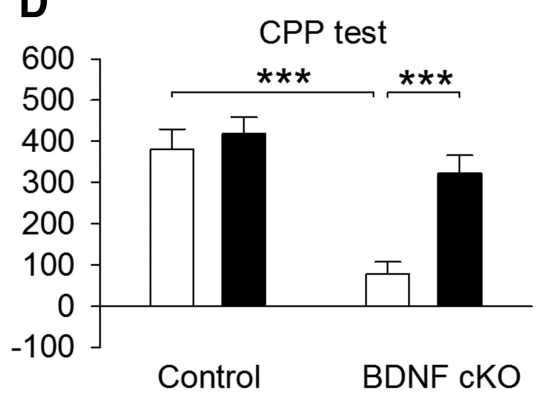

Figure 10. BDNF CKO attenuated CPP to cocaine. $A$, Wild-type control and BDNF CKO mice exhibited no significant unconditioned preference in each chamber during pretest $(n=9-11$ for each group; $p>0.05)$. $\boldsymbol{B}$, Mice received saline $(0.9 \% \mathrm{NaCl}$, i.p. $)$ and cocaine $(15 \mathrm{mg} / \mathrm{kg})$ place conditioning once daily for $6 \mathrm{~d}$. CPP was tested $24 \mathrm{~h}$ after the last conditioning. BDNF cKO significantly decreased the CPP score in cocaine-conditioned mice $\left({ }^{* *} p<0.01\right)$ but did not affect the CPP score in saline-conditioned mice $(p>$ 0.05). $\boldsymbol{C}, \boldsymbol{D}$, Same as in $\boldsymbol{A}, \boldsymbol{B}$, wild-type control and BDNF $C K O$ mice underwent cocaine conditioning. There was no unconditioned place preference during pretest ( $n=9$ or 10 for each group; $p>0.05$; $)$. The mice were pretreated with vehicle or DHF $(5 \mathrm{mg} / \mathrm{kg}$, i.p.) before each saline or cocaine conditioning. (PP was significantly attenuated in vehicle-pretreated BDNF CKO mice compared with vehicle-pretreated wild-type mice $\left.{ }^{* * *} p<0.001\right)$, whereas DHF pretreatment significantly increased cocaine (PP in BDNF cKO mice $\left({ }^{* * *} p<0.001\right)$, but not in control mice $(p>0.05)$.

ing $\left(F_{(1,35)}=18.39, p<0.001\right)$ and $\operatorname{BDNF} \mathrm{cKO}\left(F_{(1,35)}=7.55\right.$, $p=0.009)$ had significant effects on CPP scores and there was a significant interaction between cocaine conditioning and genotype $\left(F_{(1,35)}=4.19, p=0.048\right.$; Fig. $\left.10 B\right)$. Tukey's post hoc test showed that BDNF cKO led to a significant decrease in the CPP score in cocaine-conditioned mice $(p=0.001)$ but did not have significant effect on the CPP score in saline-conditioned mice $(p=0.64)$. Thus, BDNF cKO attenuated CPP to cocaine.

We next determined whether the impairment of cocaine CPP in $B D N F$ cKO mice could be rescued by systemic administration of TrkB agonist DHF. Wild-type control and $B D N F$ cKO mice underwent cocaine conditioning as described above. There was no unconditioned place preference during pretest (Fig. 10C). The mice were then pretreated with vehicle or DHF $(5 \mathrm{mg} / \mathrm{kg}$, i.p.) before each saline or cocaine conditioning. Two-way ANOVA revealed that genotype $\left(F_{(1,34)}=24.10, p<0.001\right)$ and drug pretreatments $\left(F_{(1,34)}=12.28, p=\right.$ 0.001 ) had significant main effects on CPP scores and there was a significant interaction between cocaine conditioning and genotype $\left(F_{(1,34)}=6.49, p=0.016\right.$; Fig. $\left.10 D\right)$. Tukey's post hoc test showed that CPP was significantly attenuated in vehicle-pretreated $B D N F$ cKO mice compared with vehiclepretreated wild-type mice $(p<0.001)$, and DHF pretreatment significantly increased cocaine CPP in BDNF $c K O$ mice $(p<0.001)$, but not in control mice $(p=$ $0.51)$. These results suggest that the impairment of cocaine CPP in BDNF $c K O$ mice could be attributed to lack of BDNF.

We examined whether the $C_{1}$ receptor is required for DHF-induced restoration of cocaine CPP in BDNF $c K O$ mice. $B D N F$ cKO mice underwent cocaine conditioning as described above. BDNF $c K O$ mice were then given intraperitoneal injections of either the $\mathrm{CB}_{1}$ antagonist AM251 (3 mg/kg) or AM251 (3 mg/kg) plus DHF $(5 \mathrm{mg} / \mathrm{kg})$ before each place conditioning. For comparison, the CPP scores from these two groups were analyzed together with those from $B D N F c K O$ mice that received intraperitoneal injections of vehicle or DHF before conditioning in Figure 10D. One-way ANOVA revealed that the preference scores were significantly different among the four treatment groups (i.e., vehicle, DHF, AM251, and $\left.\mathrm{AM} 251+\mathrm{DHF} ; F_{(3,38)}=7.94, p<0.001\right)$. Tukey's post hoc test indicated that the DHF-induced restoration of cocaine CPP in $B D N F$ cKO mice was significantly attenuated by AM251 ( $p=0.025)$, whereas AM251 did not further decrease the preference score in BDNF $c K O$ mice compared with the vehicle group $(p=0.99)$ (Fig. 11A). These results suggest that the $\mathrm{CB}_{1}$ receptor is one of the downstream effectors responsible for the DHF-induced restoration of cocaine CPP in BDNF $c K O$ mice.

We also repeated the above AM251 experiments in wild-type control mice. These mice were given intraperitoneal injections of AM251 or AM251 plus DHF before place conditioning. For comparison, the preference scores from these two groups were also analyzed together with those from wild-type control mice in Figure $10 D$. One-way ANOVA showed that the preference scores were significantly different among the four treatment groups in wild-type control mice $\left(F_{(3,33)}=5.85, p=0.003\right)$. Tukey's post hoc test indicated that AM251 significantly decreased the prefer- 
A

Cocaine conditioning
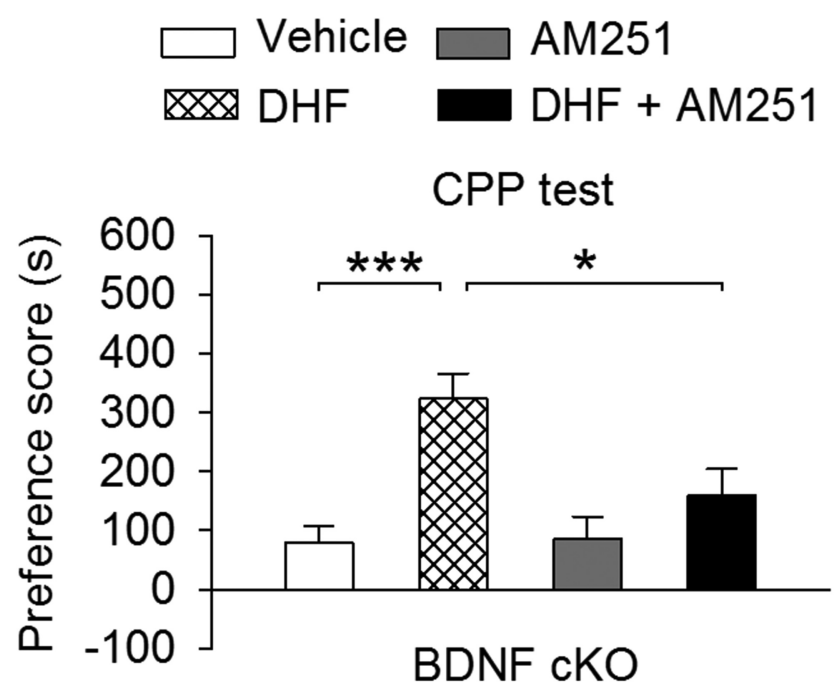

B

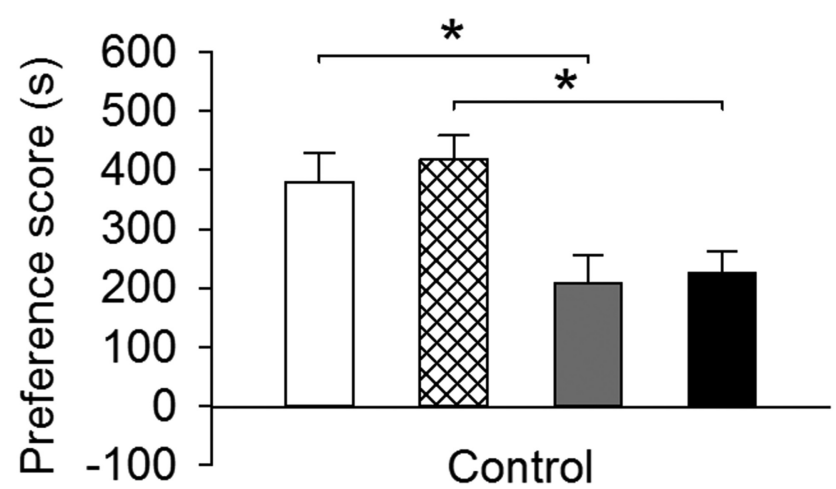

Figure 11. $\quad C_{1}$ receptor antagonism blocked DHF-induced restoration of cocaine $C P P$ in $B D N F$ CKO mice and attenuated cocaine CPP in wild-type mice. $A$, Before each place conditioning, BDNF CKO mice received intraperitoneal injections of AM251 (3 mg/kg) or AM251 + DHF (5 $\mathrm{mg} / \mathrm{kg}$ ). The preference scores were plotted together with vehicle and DHF groups in BDNF $K O$ mice from Figure 10D. DHF restored cocaine CPP in BDNF CKO mice (*** $p<0.001)$. AM251 blocked DHF-induced restoration of cocaine CPP in BDNF CKO mice $\left({ }^{*} p<0.05\right)$ but had no significant effect on the preference score compared with that in vehicle-treated $B D N F C K O$ mice ( $n=10-12$ for each group; $p>0.05$ ). $\boldsymbol{B}$, Before each place conditioning, wild-type control mice received intraperitoneal injections of AM251 or AM251 + DHF. The preference scores were plotted together with vehicle and DHF groups in wild-type control mice from Figure $10 D$. AM251 significantly decreased the preference score in wild-type control mice compared with vehicle treatment group $\left({ }^{*} p<0.05\right)$. The AM251 + DHF group exhibited significant decrease in the preference score compared with the DHF group ( $n=9$ or 10 for each group; ${ }^{*} p<0.05$ ).

ence score in wild-type control mice compared with vehicle treatment group ( $p=0.042$ ); the AM251 + DHF treatment group exhibited a significant decrease in the preference score compared with the DHF treatment group ( $p=0.023$ ) (Fig. 11B).

\section{Discussion}

Here we have found that TrkB agonists BDNF and DHF activated the TrkB receptor to enable eCB-mediated DSI and I-LTD in VTA dopamine neurons. BDNF cKO from dopamine neurons attenuated cocaine-induced inhibitory and excitatory synaptic plasticity and CPP. Systemic administration of DHF rescued cocaine CPP in BDNF cKO mice; this behavioral effect of DHF was attenuated by the $\mathrm{CB}_{1}$ antagonist AM251. These results uncovered a key role of BDNF-eCB interaction in regulating cocaineinduced synaptic plasticity and associative learning.

\section{Facilitation of DSI and I-LTD by BDNF}

Depolarization of VTA dopamine neurons was not sufficient to induce DSI, and electrical stimulation at $10 \mathrm{~Hz}$ for 5 min was subthreshold for I-LTD induction. However, the presence of BDNF or DHF enabled DSI and I-LTD, and the effects of BDNF and DHF were blocked by TrkB inhibitor K252a or TrkB antagonist CTX-B. DSI and I-LTD are mediated by 2-AG-induced activation of $\mathrm{CB}_{1}$ receptors (Chevaleyre and Castillo, 2003; Pan et al., 2009; Gao et al., 2010; Tanimura et al., 2010). An increase in 2-AG production might explain BDNF-induced facilitation of DSI and I-LTD. PLC and DAG lipases are key enzymes for 2-AG synthesis. PLC cleaves PIP2 into DAG and IP3. DAG is subsequently converted into 2-AG by diacylglycerol lipase (DAGL) (Stella et al., 1997; Di Marzo et al., 1998; Piomelli et al., 2000). There are five types of PLC $(\beta, \gamma, \delta, \varepsilon$, and $\zeta)$ (Rebecchi and Pentyala, 2000). $\mathrm{G}_{\mathrm{q} / 11}$-coupled receptors, such as Group I mGluRs, activate PLC $\beta$ to enhance 2-AG production (Maejima et al., 2001; Hashimotodani et al., 2005; Di Marzo, 2011). BDNF is coupled to PLC $\gamma$ (Reichardt, 2006); the activation of PLC $\gamma$ DAG pathway may also enhance 2-AG production. BDNF depresses IPSCs in neocortical layer $2 / 3$ pyramidal neurons, and this depression is blocked by a $\mathrm{CB}_{1}$ antagonist or PLC inhibitor (Lemtiri-Chlieh and Levine, 2010; Zhao and Levine, 2014). We showed that I-LTD- and BDNF-induced depression of IPSCs was blocked by PLC and DAG lipase inhibitors. These results suggest that BDNF facilitates DSI and I-LTD by enhancing 2-AG synthesis via the PLC $\gamma$-DAG pathway. However, this conclusion should be interpreted with caution since currently available PLC and DAG lipase inhibitors have off-target effects (Walker et al., 1998; Hoover et al., 2008).

Incubation of BDNF for $4-24 \mathrm{~h}$ increases $\mathrm{CB}_{1}$ receptor transcripts and decreases MAGL transcripts in cultured cerebellar granule neurons (Maison et al., 2009), whereas acute bath application of BDNF inhibited $\mathrm{CB}_{1}$ agonist-induced depression of IPSCs in striatal slices through a mechanism mediated by altered cholesterol metabolism and membrane lipid raft function (De Chiara et al., 2010). We also considered the possibility that BDNF and DHF might facilitate DSI and I-LTD by enhancing $\mathrm{CB}_{1}$ receptor responsiveness or decreasing MAGL activity. However, we found that DHF did not significantly alter WIN 55212-2-induced depression of IPSCs, suggesting that acute treatment with TrkB agonists does not significantly alter $\mathrm{CB}_{1}$ receptor function in the VTA. In addition, time course comparison of DSI induced in BDNF, DHF, DHPG, and JZL184 suggests that BDNF and DHF do not significantly alter MAGL activity.

\section{The requirement of $\mathrm{BNDF}-\mathrm{eCB}$ interaction in regulating cocaine-induced synaptic plasticity}

We have shown that repeated intraperitoneal cocaine injections for $5-7 \mathrm{~d}$ reduce the strength of GABAergic inhibition to VTA dopamine neurons (Liu et al., 2005; Pan et al., 2008b). Our previous studies suggest that $\mathrm{eCB}$-dependent I-LTD constitutes a mechanism for cocaine-induced reduction of GABAergic inhibition (Pan et al., 2008a, b). Given that BDNF plays a critical role in I-LTD, we examined whether it is required for the reduction of GABAergic inhibition to VTA dopamine neurons induced by repeated cocaine exposure in vivo. We found that dopamine neuron-specific knock-out of BDNF blocked cocaine-induced decreases in the amplitude of maximal IPSCs and mIPSCs. Our 
results appear to support a model in which BDNF-eCB interaction is required for cocaine-induced reduction of GABAergic inhibition to VTA dopamine neurons. A direct consequence of reduction of GABAergic inhibition is to prime excitatory synapses for potentiation. Indeed, BDNF cKO prevented the increase in the AMPAR/NMDAR ratio induced by repeated cocaine exposure in vivo. These results suggest a critical role of BDNF in regulating cocaine-induced excitatory and inhibitory synaptic plasticity in the VTA. BDNF cKO did not significantly alter the amplitude of maximal IPSCs and mIPSCs and AMPAR/NMDAR ratio in saline-treated mice, suggesting that BDNF is not essential for basal inhibitory and excitatory synaptic transmission. Either acute loss of BDNF or associated developmental changes could explain the effects of BDNF cKO on cocaine-induced synaptic plasticity in the VTA. Future studies are needed to distinguish between these two possibilities.

\section{The effects of BDNF cKO on cocaine CPP}

BDNF has been implicated in behavioral effects of cocaine (for review, see Corominas et al., 2007; McGinty et al., 2010). BDNF protein levels are increased in the VTA, NAc, and amygdala after 30-90 d withdrawal from cocaine self-administration (Grimm et al., 2003). Local infusion of BDNF produces brain region-specific effects on cocaine seeking. Infusion of BDNF into subcortical structures, such as VTA and NAc, enhances cocaine seeking (Lu et al., 2004; Graham et al., 2007), whereas infusion of BDNF antibody into the NAc or localized BDNF deletion in the NAc attenuates cocaine-induced reinstatement (Graham et al., 2007) and cocaine CPP (Graham et al., 2009). In contrast, BDNF infusion into the dorsomedial PFC suppresses cocaine seeking (Berglind et al., 2007). Lentiviral expression of BDNF or TrkB in the NAc of the rat enhanced cocaine-induced behavioral sensitization and CPP, delayed CPP-extinction upon repeated measurements, and increased CPP reinstatement. Conversely, lentiviral expression of a truncated form of TrkB inhibited these behavioral changes (Bahi et al., 2008). Most relevant to the present study is the finding that genetic deletion of BDNF with adeno-associated viral (AAV) vector-carrying the Cre recombinase (AAV-CreGFP) in the VTA of $B d n f^{\text {foxPlloxP }}$ mice reduced cocaine CPP (Graham et al., 2009). However, the AAV-Cre-GFP deletes BDNF in both dopamine neurons and nondopamine neurons in the VTA. In the present study, we generated dopamine neuron-specific BNDF knock-out mice by crossing homozygous $B d n f$ foxP/lox $P$ mice with heterozygous DAT-Cre $e^{+/-}$mice. Consistent with the AAV-Cre-GFP approach (Graham et al., 2009), we found that cocaine CPP was greatly attenuated in BNDF cKO mice compared with wild-type mice. This attenuation of cocaine CPP could be rescued by systemic administration of TrkB agonist DHF. Together, the above studies suggest that the behavioral deficiency in cocaine-cue learning can be attributed to the lack of BDNF, although we cannot rule out the possibility that developmental changes after $B D N F c K O$ may also play a role. Long-term synaptic plasticity in brain's reward circuit may represent a putative mechanism for the learned association between environmental cues and rewarding effects of cocaine (Kauer, 2004; Hyman et al., 2006). The impairment of cocaine-induced synaptic plasticity might help explain the deficiency in cocaine CPP in BDNF $c K O$ mice.

The eCB system has been implicated in behavioral effects of cocaine (Lupica and Riegel, 2005; Wiskerke et al., 2008). Systemic or local infusions of $\mathrm{CB}_{1}$ antagonists into the nucleus accumbens attenuated cocaine seeking (Xi et al., 2006, 2008). $\mathrm{CB}_{1}$ agonists trigger relapse to cocaine seeking after prolonged cocaine with- drawal, whereas $\mathrm{CB}_{1}$ antagonists attenuate relapse induced by cocaine or cocaine-associated cues (De Vries et al., 2001). $\mathrm{CB}_{1}$ knock-out mice exhibited reduced cocaine self-administration (Soria et al., 2005) but normal CPP to cocaine (Martin et al., 2000; Houchi et al., 2005). In contrast, intraperitoneal injections of a $\mathrm{CB}_{1}$ antagonist blocked the acquisition, but not the expression, of cocaine CPP (Chaperon et al., 1998). Consistent with the latter finding, we have shown that intra-VTA injections of the $\mathrm{CB}_{1}$ antagonist AM251 before each place conditioning attenuated the acquisition of CPP to cocaine (Pan et al., 2011). Constitutive knock-out of genes is known to produce compensatory effects. It is unclear whether a compensatory mechanism could explain differential effects on cocaine $\mathrm{CPP}$ by the $\mathrm{CB}_{1}$ antagonist and $\mathrm{CB}_{1}$ knock-out. Nevertheless, the above studies suggest that the $\mathrm{eCB} / \mathrm{CB}_{1}$ signaling system is critically involved in cocaine reward and seeking. We have shown that intraperitoneal injection of $\mathrm{CB}_{1}$ antagonist AM251 attenuated cocaine CPP in wildtype mice and blocked DHF-induced restoration of cocaine CPP in $B D N F c K O$ mice. These results suggest that the $\mathrm{CB}_{1}$ receptor is an important downstream target of BDNF and that BDNF-CB signaling in the VTA is critically involved in cocaine-cue associative learning. Given that BDNF and $\mathrm{CB} 1$ receptors are important modulators of synaptic plasticity, we suspect that modulation of cocaine-induced synaptic plasticity may be responsible for the behavioral effects of DHF and AM251. However, the TrkB receptor can activate a variety of downstream targets (Reichardt, 2006); we cannot exclude the possibility that DHF may activate other targets to restore CPP to cocaine.

In conclusion, we have shown that BDNF and DHF facilitate eCB-mediated DSI and I-LTD, and BDNF conditional knock-out leads to impairments of eCB-mediated I-LTD and cocaineinduced excitatory and inhibitory synaptic plasticity in VTA dopamine neurons. In addition, $\mathrm{BDNF}-\mathrm{CB}_{1}$ signaling is also involved in cocaine-cue associated learning as indicated by cocaine CPP experiments. Together, the present study suggests that the BDNF-eCB interaction plays a critical role in mediating cocaineinduced long-term synaptic plasticity and behavioral effects.

\section{References}

Bäckman CM, Malik N, Zhang Y, Shan L, Grinberg A, Hoffer BJ, Westphal H, Tomac AC (2006) Characterization of a mouse strain expressing Cre recombinase from the $3^{\prime}$ untranslated region of the dopamine transporter locus. Genesis 44:383-390. CrossRef Medline

Bahi A, Boyer F, Chandrasekar V, Dreyer JL (2008) Role of accumbens BDNF and TrkB in cocaine-induced psychomotor sensitization, conditioned-place preference, and reinstatement in rats. Psychopharmacology 199:169-182. CrossRef Medline

Berglind WJ, See RE, Fuchs RA, Ghee SM, Whitfield TW Jr, Miller SW, McGinty JF (2007) A BDNF infusion into the medial prefrontal cortex suppresses cocaine seeking in rats. Eur J Neurosci 26:757-766. CrossRef Medline

Blankman JL, Simon GM, Cravatt BF (2007) A comprehensive profile of brain enzymes that hydrolyze the endocannabinoid 2-arachidonoylglycerol. Chem Biol 14:1347-1356. CrossRef Medline

Borgland SL, Malenka RC, Bonci A (2004) Acute and chronic cocaineinduced potentiation of synaptic strength in the ventral tegmental area: electrophysiological and behavioral correlates in individual rats. J Neurosci 24:7482-7490. CrossRef Medline

Chaperon F, Soubrié P, Puech AJ, Thiébot MH (1998) Involvement of central cannabinoid (CB1) receptors in the establishment of place conditioning in rats. Psychopharmacology 135:324-332. CrossRef Medline

Chevaleyre V, Castillo PE (2003) Heterosynaptic LTD of hippocampal GABAergic synapses: a novel role of endocannabinoids in regulating excitability. Neuron 38:461-472. CrossRef Medline

Chieng B, Azriel Y, Mohammadi S, Christie MJ (2011) Distinct cellular properties of identified dopaminergic and GABAergic neurons in the 
mouse ventral tegmental area. J Physiol 589:3775-3787. CrossRef Medline

Corominas M, Roncero C, Ribases M, Castells X, Casas M (2007) Brainderived neurotrophic factor and its intracellular signaling pathways in cocaine addiction. Neuropsychobiology 55:2-13. CrossRef Medline

Cravatt BF, Giang DK, Mayfield SP, Boger DL, Lerner RA, Gilula NB (1996) Molecular characterization of an enzyme that degrades neuromodulatory fatty-acid amides. Nature 384:83-87. CrossRef Medline

De Chiara V, Angelucci F, Rossi S, Musella A, Cavasinni F, Cantarella C, Mataluni G, Sacchetti L, Napolitano F, Castelli M, Caltagirone C, Bernardi G, Maccarrone M, Usiello A, Centonze D (2010) Brain-derived neurotrophic factor controls cannabinoid CB1 receptor function in the striatum. J Neurosci 30:8127-8137. CrossRef Medline

De Vries TJ, Shaham Y, Homberg JR, Crombag H, Schuurman K, Dieben J, Vanderschuren LJ, Schoffelmeer AN (2001) A cannabinoid mechanism in relapse to cocaine seeking. Nat Med 7:1151-1154. CrossRef Medline

Di Marzo V (2011) Endocannabinoid signaling in the brain: biosynthetic mechanisms in the limelight. Nat Neurosci 14:9-15. CrossRef Medline

Di Marzo V, Melck D, Bisogno T, De Petrocellis L (1998) Endocannabinoids: endogenous cannabinoid receptor ligands with neuromodulatory action. Trends Neurosci 21:521-528. CrossRef Medline

Edwards DA, Kim J, Alger BE (2006) Multiple mechanisms of endocannabinoid response initiation in hippocampus. J Neurophysiol 95:67-75. CrossRef Medline

Gao Y, Vasilyev DV, Goncalves MB, Howell FV, Hobbs C, Reisenberg M, Shen R, Zhang MY, Strassle BW, Lu P, Mark L, Piesla MJ, Deng K, Kouranova EV, Ring RH, Whiteside GT, Bates B, Walsh FS, Williams G, Pangalos MN, et al. (2010) Loss of retrograde endocannabinoid signaling and reduced adult neurogenesis in diacylglycerol lipase knock-out mice. J Neurosci 30:2017-2024. CrossRef Medline

Gerdeman GL, Ronesi J, Lovinger DM (2002) Postsynaptic endocannabinoid release is critical to long-term depression in the striatum. Nat Neurosci 5:446-451. CrossRef Medline

Gerdeman GL, Partridge JG, Lupica CR, Lovinger DM (2003) It could be habit forming: drugs of abuse and striatal synaptic plasticity. Trends Neurosci 26:184-192. CrossRef Medline

Gong R, Ding C, Hu J, Lu Y, Liu F, Mann E, Xu F, Cohen MB, Luo M (2011) Role for the membrane receptor guanylyl cyclase-C in attention deficiency and hyperactive behavior. Science 333:1642-1646. CrossRef Medline

Graham DL, Edwards S, Bachtell RK, DiLeone RJ, Rios M, Self DW (2007) Dynamic BDNF activity in nucleus accumbens with cocaine use increases self-administration and relapse. Nat Neurosci 10:1029-1037. CrossRef Medline

Graham DL, Krishnan V, Larson EB, Graham A, Edwards S, Bachtell RK, Simmons D, Gent LM, Berton O, Bolanos CA, DiLeone RJ, Parada LF, Nestler EJ, Self DW (2009) Tropomyosin-related kinase B in the mesolimbic dopamine system: region-specific effects on cocaine reward. Biol Psychiatry 65:696-701. CrossRef Medline

Grimm JW, Lu L, Hayashi T, Hope BT, Su TP, Shaham Y (2003) Timedependent increases in brain-derived neurotrophic factor protein levels within the mesolimbic dopamine system after withdrawal from cocaine: implications for incubation of cocaine craving. J Neurosci 23:742-747. Medline

Hashimotodani Y, Ohno-Shosaku T, Tsubokawa H, Ogata H, Emoto K, Maejima T, Araishi K, Shin HS, Kano M (2005) Phospholipase Cbeta serves as a coincidence detector through its $\mathrm{Ca}^{2+}$ dependency for triggering retrograde endocannabinoid signal. Neuron 45:257-268. CrossRef Medline

Heifets BD, Castillo PE (2009) Endocannabinoid signaling and long-term synaptic plasticity. Annu Rev Physiol 71:283-306. CrossRef Medline

Hoover HS, Blankman JL, Niessen S, Cravatt BF (2008) Selectivity of inhibitors of endocannabinoid biosynthesis evaluated by activity-based protein profiling. Bioorg Med Chem Lett 18:5838-5841. CrossRef Medline

Houchi H, Babovic D, Pierrefiche O, Ledent C, Daoust M, Naassila M (2005) $\mathrm{CB} 1$ receptor knockout mice display reduced ethanol-induced conditioned place preference and increased striatal dopamine D2 receptors. Neuropsychopharmacology 30:339-349. CrossRef Medline

Huang CC, Yeh CM, Wu MY, Chang AY, Chan JY, Chan SH, Hsu KS (2011) Cocaine withdrawal impairs metabotropic glutamate receptor-dependent long-term depression in the nucleus accumbens. J Neurosci 31:4194-4203. CrossRef Medline
Huang ZJ, Kirkwood A, Pizzorusso T, Porciatti V, Morales B, Bear MF, Maffei L, Tonegawa S (1999) BDNF regulates the maturation of inhibition and the critical period of plasticity in mouse visual cortex. Cell 98:739-755. CrossRef Medline

Hyman SE, Malenka RC, Nestler EJ (2006) Neural mechanisms of addiction: the role of reward-related learning and memory. Annu Rev Neurosci 29:565-598. CrossRef Medline

Jang SW, Liu X, Yepes M, Shepherd KR, Miller GW, Liu Y, Wilson WD, Xiao G, Blanchi B, Sun YE, Ye K (2010) A selective TrkB agonist with potent neurotrophic activities by 7,8-dihydroxyflavone. Proc Natl Acad Sci U S A 107:2687-2692. CrossRef Medline

Johnson SW, North RA (1992) Two types of neurone in the rat ventral tegmental area and their synaptic inputs. J Physiol 450:455-468. CrossRef Medline

Jones S, Kauer JA (1999) Amphetamine depresses excitatory synaptic transmission via serotonin receptors in the ventral tegmental area. J Neurosci 19:9780-9787. Medline

Jung KM, Mangieri R, Stapleton C, Kim J, Fegley D, Wallace M, Mackie K, Piomelli D (2005) Stimulation of endocannabinoid formation in brain slice cultures through activation of group I metabotropic glutamate receptors. Mol Pharmacol 68:1196-1202. CrossRef Medline

Kauer JA (2004) Learning mechanisms in addiction: synaptic plasticity in the ventral tegmental area as a result of exposure to drugs of abuse. Annu Rev Physiol 66:447-475. CrossRef Medline

Kim SJ, Kim YS, Yuan JP, Petralia RS, Worley PF, Linden DJ (2003) Activation of the TRPC1 cation channel by metabotropic glutamate receptor mGluR1. Nature 426:285-291. CrossRef Medline

Kreitzer AC, Regehr WG (2001) Retrograde inhibition of presynaptic calcium influx by endogenous cannabinoids at excitatory synapses onto Purkinje cells. Neuron 29:717-727. CrossRef Medline

Lemtiri-Chlieh F, Levine ES (2010) BDNF evokes release of endogenous cannabinoids at layer $2 / 3$ inhibitory synapses in the neocortex. J Neurophysiol 104:1923-1932. CrossRef Medline

Liu QS, Pu L, Poo MM (2005) Repeated cocaine exposure in vivo facilitates LTP induction in midbrain dopamine neurons. Nature 437:1027-1031. CrossRef Medline

Liu X, Liu Y, Zhong P, Wilkinson B, Qi J, Olsen CM, Bayer KU, Liu QS (2014) CaMKII activity in the ventral tegmental area gates cocaineinduced synaptic plasticity in the nucleus accumbens. Neuropsychopharmacology 39:989-999. CrossRef Medline

Lobo MK, Covington HE 3rd, Chaudhury D, Friedman AK, Sun H, DamezWerno D, Dietz DM, Zaman S, Koo JW, Kennedy PJ, Mouzon E, Mogri M, Neve RL, Deisseroth K, Han MH, Nestler EJ (2010) Cell type-specific loss of BDNF signaling mimics optogenetic control of cocaine reward. Science 330:385-390. CrossRef Medline

Long JZ, Li W, Booker L, Burston JJ, Kinsey SG, Schlosburg JE, Pavón FJ, Serrano AM, Selley DE, Parsons LH, Lichtman AH, Cravatt BF (2009) Selective blockade of 2-arachidonoylglycerol hydrolysis produces cannabinoid behavioral effects. Nat Chem Biol 5:37-44. CrossRef Medline

Lu H, Cheng PL, Lim BK, Khoshnevisrad N, Poo MM (2010) Elevated BDNF after cocaine withdrawal facilitates LTP in medial prefrontal cortex by suppressing GABA inhibition. Neuron 67:821-833. CrossRef Medline

Lu L, Dempsey J, Liu SY, Bossert JM, Shaham Y (2004) A single infusion of brain-derived neurotrophic factor into the ventral tegmental area induces long-lasting potentiation of cocaine seeking after withdrawal. J Neurosci 24:1604-1611. CrossRef Medline

Luongo L, Maione S, Di Marzo V (2014) Endocannabinoids and neuropathic pain: focus on neuron-glia and endocannabinoid-neurotrophin interactions. Eur J Neurosci 39:401-408. CrossRef Medline

Lupica CR, Riegel AC (2005) Endocannabinoid release from midbrain dopamine neurons: a potential substrate for cannabinoid receptor antagonist treatment of addiction. Neuropharmacology 48:1105-1116. CrossRef Medline

Maejima T, Hashimoto K, Yoshida T, Aiba A, Kano M (2001) Presynaptic inhibition caused by retrograde signal from metabotropic glutamate to cannabinoid receptors. Neuron 31:463-475. CrossRef Medline

Maison P, Walker DJ, Walsh FS, Williams G, Doherty P (2009) BDNF regulates neuronal sensitivity to endocannabinoids. Neurosci Lett 467:9094. CrossRef Medline

Mameli M, Halbout B, Creton C, Engblom D, Parkitna JR, Spanagel R, Lüscher C (2009) Cocaine-evoked synaptic plasticity: persistence in the 
VTA triggers adaptations in the NAc. Nat Neurosci 12:1036-1041. CrossRef Medline

Marsicano G, Wotjak CT, Azad SC, Bisogno T, Rammes G, Cascio MG, Hermann H, Tang J, Hofmann C, Zieglgänsberger W, Di Marzo V, Lutz B (2002) The endogenous cannabinoid system controls extinction of aversive memories. Nature 418:530-534. CrossRef Medline

Martin M, Ledent C, Parmentier M, Maldonado R, Valverde O (2000) Cocaine, but not morphine, induces conditioned place preference and sensitization to locomotor responses in CB1 knockout mice. Eur J Neurosci 12:4038-4046. CrossRef Medline

McGinty JF, Whitfield TW Jr, Berglind WJ (2010) Brain-derived neurotrophic factor and cocaine addiction. Brain Res 1314:183-193. CrossRef Medline

Ohno-Shosaku T, Maejima T, Kano M (2001) Endogenous cannabinoids mediate retrograde signals from depolarized postsynaptic neurons to presynaptic terminals. Neuron 29:729-738. CrossRef Medline

Pan B, Hillard CJ, Liu QS (2008a) D2 dopamine receptor activation facilitates endocannabinoid-mediated long-term synaptic depression of GABAergic synaptic transmission in midbrain dopamine neurons via cAMP-protein kinase A signaling. J Neurosci 28:14018-14030. CrossRef Medline

Pan B, Hillard CJ, Liu QS (2008b) Endocannabinoid signaling mediates cocaine-induced inhibitory synaptic plasticity in midbrain dopamine neurons. J Neurosci 28:1385-1397. CrossRef Medline

Pan B, Wang W, Long JZ, Sun D, Hillard CJ, Cravatt BF, Liu QS (2009) Blockade of 2-arachidonoylglycerol hydrolysis by selective monoacylglycerol lipase inhibitor 4-nitrophenyl 4-(dibenzo[d] [1,3] dioxol-5-yl(hydroxy)methyl)piperidine-1carboxylate (JZL184) enhances retrograde endocannabinoid signaling. J Pharmacol Exp Ther 331:591-597. CrossRef Medline

Pan B, Zhong P, Sun D, Liu QS (2011) Extracellular signal-regulated kinase signaling in the ventral tegmental area mediates cocaine-induced synaptic plasticity and rewarding effects. J Neurosci 31:11244-11255. CrossRef Medline

Park H, Poo MM (2013) Neurotrophin regulation of neural circuit development and function. Nat Rev 14:7-23. CrossRef Medline

Piomelli D (2003) The molecular logic of endocannabinoid signalling. Nat Rev 4:873-884. CrossRef Medline

Piomelli D, Giuffrida A, Calignano A, Rodriguez de Fonseca F (2000) The endocannabinoid system as a target for therapeutic drugs. Trends Pharmacol Sci 21:218-224. Medline

Pu L, Liu QS, Poo MM (2006) BDNF-dependent synaptic sensitization in midbrain dopamine neurons after cocaine withdrawal. Nat Neurosci 9:605-607. CrossRef Medline

Rebecchi MJ, Pentyala SN (2000) Structure, function, and control of phosphoinositide-specific phospholipase C. Physiol Rev 80:1291-1335. Medline

Reichardt LF (2006) Neurotrophin-regulated signalling pathways. Philos Trans R Soc Lond B Biol Sci 361:1545-1564. CrossRef Medline

Robbe D, Kopf M, Remaury A, Bockaert J, Manzoni OJ (2002) Endogenous cannabinoids mediate long-term synaptic depression in the nucleus accumbens. Proc Natl Acad Sci U S A 99:8384-8388. CrossRef Medline

Saal D, Dong Y, Bonci A, Malenka RC (2003) Drugs of abuse and stress trigger a common synaptic adaptation in dopamine neurons. Neuron 37:577-582. CrossRef Medline

Safo PK, Regehr WG (2005) Endocannabinoids control the induction of cerebellar LTD. Neuron 48:647-659. CrossRef Medline

Soria G, Mendizábal V, Touriño C, Robledo P, Ledent C, Parmentier M,
Maldonado R, Valverde O (2005) Lack of CB1 cannabinoid receptor impairs cocaine self-administration. Neuropsychopharmacology 30 : 1670-1680. CrossRef Medline

Stella N, Schweitzer P, Piomelli D (1997) A second endogenous cannabinoid that modulates long-term potentiation. Nature 388:773-778. Medline

Tanimura A, Yamazaki M, Hashimotodani Y, Uchigashima M, Kawata S, Abe M, Kita Y, Hashimoto K, Shimizu T, Watanabe M, Sakimura K, Kano M (2010) The endocannabinoid 2-arachidonoylglycerol produced by diacylglycerol lipase alpha mediates retrograde suppression of synaptic transmission. Neuron 65:320-327. CrossRef Medline

Tozzi A, Bengtson CP, Longone P, Carignani C, Fusco FR, Bernardi G, Mercuri NB (2003) Involvement of transient receptor potential-like channels in responses to mGluR-I activation in midbrain dopamine neurons. Eur J Neurosci 18:2133-2145. CrossRef Medline

Ungless MA, Whistler JL, Malenka RC, Bonci A (2001) Single cocaine exposure in vivo induces long-term potentiation in dopamine neurons. Nature 411:583-587. CrossRef Medline

Varma N, Carlson GC, Ledent C, Alger BE (2001) Metabotropic glutamate receptors drive the endocannabinoid system in hippocampus. J Neurosci 21:RC188. Medline

Walker EM, Bispham JR, Hill SJ (1998) Nonselective effects of the putative phospholipase C inhibitor, U73122, on adenosine A1 receptor-mediated signal transduction events in Chinese hamster ovary cells. Biochem Pharmacol 56:1455-1462. CrossRef Medline

Wilson RI, Nicoll RA (2001) Endogenous cannabinoids mediate retrograde signalling at hippocampal synapses. Nature 410:588-592. CrossRef Medline

Wiskerke J, Pattij T, Schoffelmeer AN, De Vries TJ (2008) The role of CB1 receptors in psychostimulant addiction. Addict Biol 13:225-238. CrossRef Medline

Xi ZX, Gilbert JG, Peng XQ, Pak AC, Li X, Gardner EL (2006) Cannabinoid CB1 receptor antagonist AM251 inhibits cocaine-primed relapse in rats: role of glutamate in the nucleus accumbens. J Neurosci 26:8531-8536. CrossRef Medline

Xi ZX, Spiller K, Pak AC, Gilbert J, Dillon C, Li X, Peng XQ, Gardner EL (2008) Cannabinoid $\mathrm{CB} 1$ receptor antagonists attenuate cocaine's rewarding effects: experiments with self-administration and brain-stimulation reward in rats. Neuropsychopharmacology 33:1735-1745. CrossRef Medline

Yu F, Zhong P, Liu X, Sun D, Gao HQ, Liu QS (2013) Metabotropic glutamate receptor I (mGluR1) antagonism impairs cocaine-induced conditioned place preference via inhibition of protein synthesis. Neuropsychopharmacology 38 : 1308-1321. CrossRef Medline

Zhao L, Levine ES (2014) BDNF-endocannabinoid interactions at neocortical inhibitory synapses require phospholipase C signaling. J Neurophysiol 111:1008-1015. CrossRef Medline

Zhong P, Wang W, Yu F, Nazari M, Liu X, Liu QS (2012) Phosphodiesterase 4 inhibition impairs cocaine-induced inhibitory synaptic plasticity and conditioned place preference. Neuropsychopharmacology 37:2377-2387. CrossRef Medline

Zhong P, Liu X, Zhang Z, Hu Y, Liu SJ, Lezama-Ruiz M, Joksimovic M, Liu QS (2014) Cyclin-dependent kinase 5 in the ventral tegmental area regulates depression-related behaviors. J Neurosci 34:6352-6366. CrossRef Medline

Zhu PJ, Lovinger DM (2005) Retrograde endocannabinoid signaling in a postsynaptic neuron/synaptic bouton preparation from basolateral amygdala. J Neurosci 25:6199-6207. CrossRef Medline 